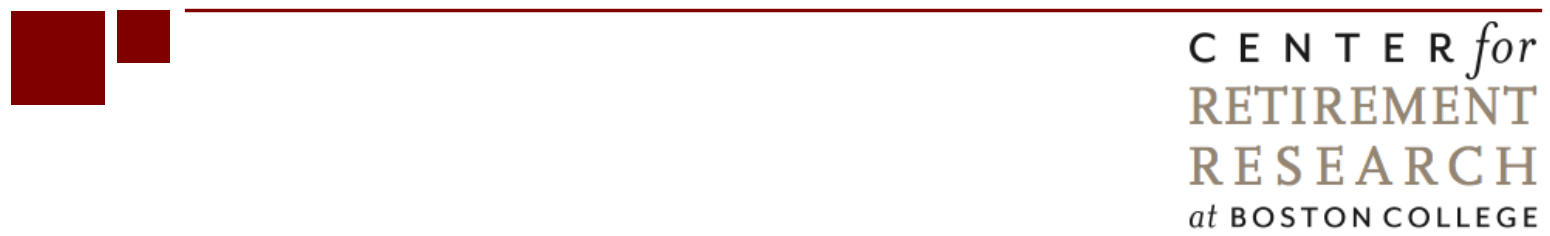

\title{
DOES HOUSEHOLD DEBT INFLUENCE THE LABOR SUPPLY AND BENEFIT CLAIMING DECISIONS OF OLDER AMERICANS?
}

\author{
Barbara A. Butrica and Nadia S. Karamcheva
}

CRR WP 2013-22

Submitted: October 2013

Released: December 2013
Center for Retirement Research at Boston College
Hovey House
140 Commonwealth Avenue
Chestnut Hill, MA 02467

Tel: 617-552-1762 Fax: 617-552-0191

http://crr.bc.edu

Barbara A. Butrica is a senior research associate and Nadia S. Karamcheva is a research associate at the Urban Institute. The research reported herein was pursuant to a grant from the U.S. Social Security Administration (SSA), funded as part of the Retirement Research Consortium (RRC). The findings and conclusions expressed are solely those of the authors and do not represent the views of SSA, any agency of the federal government, the RRC, the Urban Institute, or Boston College. The authors thank Rich Johnson, Josh Mitchell, John Sabelhaus, and the participants of the $15^{\text {th }}$ annual Retirement Research Consortium meeting and the Urban Institute Brown Bag Seminar for valuable comments and suggestions. All errors are their own.

(C) 2013, Barbara A. Butrica and Nadia S. Karamcheva. All rights reserved. Short sections of text, not to exceed two paragraphs, may be quoted without explicit permission provided that full credit, including $\odot$ notice, is given to the source. 


\begin{abstract}
About the Center for Retirement Research
The Center for Retirement Research at Boston College, part of a consortium that includes parallel centers at the University of Michigan and the National Bureau of Economic Research, was established in 1998 through a grant from the Social Security Administration. The Center's mission is to produce first-class research and forge a strong link between the academic community and decision-makers in the public and private sectors around an issue of critical importance to the nation's future. To achieve this mission, the Center sponsors a wide variety of research projects, transmits new findings to a broad audience, trains new scholars, and broadens access to valuable data sources.
\end{abstract}

\author{
Center for Retirement Research at Boston College \\ Hovey House \\ 140 Commonwealth Avenue \\ Chestnut Hill, MA 02467 \\ phone: 617-552-1762 fax: 617-552-0191 \\ e-mail: crr@bc.edu \\ crr.bc.edu
}

Affiliated Institutions:

The Brookings Institution

Massachusetts Institute of Technology

Syracuse University

Urban Institute 


\begin{abstract}
Americans' indebtedness has increased dramatically since the $1980 \mathrm{~s}-$ a trend likely to have important implications for retirement security. This study finds that older adults with debt are 8 percentage points more likely to work and 2 percentage points less likely to receive Social Security benefits than those without debt. Not only does the presence of debt influence older adults' behavior, but so do the amount and type of debt - particularly outstanding mortgages. Increasingly, retirement security will depend on having enough income and assets to pay for basic living expenses and to service debt.
\end{abstract}




\section{Introduction}

According to data tracked by the Federal Reserve System's Board of Governors, Americans' indebtedness increased dramatically from the late 1980s until just before the Great Recession. In 2007, the typical family with debt owed \$70,600, up from \$25,300 in 1989 (Federal Reserve Board 2010). By 2010, the median value of debt for families with debt was $\$ 70,700$, with debt payments accounting for about 18 percent of their disposable income (Bricker et al. 2012). Older families, in particular, experienced the largest increases in debt over the period. Between 1989 and 2010, the median value of their debt increased between 5 and 6 times. In contrast, the median value of debt among younger families only doubled.

Indebtedness could affect older adults in two different ways. On one hand, debt might compel older individuals to keep working and delay Social Security benefit claiming into their mid-sixties and beyond so they can pay off their financial obligations. On the other hand, indebted adults who are cash-strapped and unable to service their debt because they are not working (as a result unemployment or poor health, for example) or because they do not earn much might claim their benefits as soon as they are eligible in order to obtain the necessary cash to make their loan payments. Determining which of these two opposing effects dominates and how debt influences labor supply and claiming decisions is an empirical question whose answer has important implications for individuals' economic well-being in retirement and for the Social Security program itself. The source of the debt, such as whether it is tied to one's home or owed on credit cards, may also affect claiming decisions.

People can begin collecting Social Security worker benefits as early as age 62, but early claimants receive lower monthly benefits for the rest of their lives. Benefits are also reduced $\$ 1$ for every $\$ 2$ earned above a certain threshold $(\$ 15,120$ in 2013) for beneficiaries who work before reaching Social Security's full retirement age (FRA). Thus, the decision to claim benefits early can negatively impact one's own retirement security, and potentially one's spouse's. Moreover, delayed claiming confers substantial financial gains to most older adults who continue working while waiting to collect Social Security. Butrica, Smith, and Steuerle (2007) estimate that people could increase their annual consumption at older ages more than half by delaying retirement for five years, and 9 percent by waiting only one year. The additional earnings from working longer can also generate income and payroll tax revenues, helping to finance Social 
Security and other government services. Butrica, Smith, and Steuerle (2007) estimate that delaying retirement one year would reduce the Social Security deficit in 2045 by 2 percent.

To our knowledge, this is the first paper to explore the link between older adults' indebtedness and their labor supply and Social Security benefit receipt. As the level of indebtedness among older households rises and scheduled increases in the FRA boost the penalties for early claiming, understanding this relationship is especially important.

\section{Background}

Although early claiming has declined over the last decade, it remains commonplace today (Johnson, Smith and Haaga 2013; Song and Manchester 2007). More than half of all Social Security beneficiaries claim their benefits before reaching the FRA (Social Security Administration 2012, table 6.A3). Previous literature has extensively examined the characteristics of early claimants. Burkhauser, Couch, and Phillips (1996) and Panis et al. (2002) find that the majority of them are in good health and receiving employer-sponsored pension benefits. Haaga and Johnson (2012) find that early claiming is more prevalent among women, adults with limited education, and those with health problems, and that it varies significantly with macroeconomic conditions, such as high unemployment. Von Wachter (2009) also finds that trends in earnings inequality and the education distribution have significantly impacted the claiming age. Muldoon and Kopcke (2008) find that most households have sufficient financial wealth to delay claiming Social Security benefits, yet they claim early. Sass, Sun, and Webb (2007) find a positive association of later claiming and college education for married men, which they cautiously interpret to indicate greater financial awareness. Coile et al. (2002) estimate a hazard model of delayed retirement and find a U-shaped pattern with respect to wealth.

Studies that examined the optimal claiming age usually conclude that most individuals claim too early. Munnell and Soto (2005), for example, show that the optimal combination of claiming ages for a household depends on the ratio of the wife's and husband's primary insurance amount (PIA) as well as their age difference. They find that while it is often optimal for the wife to claim early, it is usually optimal for the husband to delay. Sass, Sun and Webb (2007) also find that most married men claim Social Security benefits earlier than the age that maximizes the household's expected present value of benefits. Moreover, most of the loss is borne by the survivor beneficiary, which could severely jeopardize the economic situation of many elderly widows. Using a utility-equivalence scale, Sun and Webb (2009) estimate how 
much households lose by claiming at age 62 rather than at optimal ages. They conclude that Social Security benefits would have to increase by as much as 19 percent to equalize the expected utility of non-liquidity constrained households who claim at sub-optimal ages and those who claim at the optimal combination of ages.

None of the previous papers, however, have explored the link between Social Security claiming decisions and household indebtedness or liquidity constraints. With the rising level of indebtedness among older households, and scheduled increases in FRA, thus larger penalties for early claiming, understanding the direction of the effect of debt and liquidity constraints on benefit claiming will be important for policymakers to understand. The purpose of this study is to fill this gap in the literature.

The importance of liquidity constraints has received a lot of attention in the consumption theory literature, where they have been identified as one of the possible explanations for why individuals' consumption behavior deviates from the permanent income/lifecycle model (Caroll 2001; Zeldes 1989). The majority of those studies, however, assume exogenous, even stochastic, labor supply and income. Recent literature has presented empirical evidence that households adjust not just consumption, but also their labor supply in the presence of borrowing constraints. Studies of the effects of credit market imperfections on households' labor supply decisions often find significant positive effects, particularly among women and homeowners (Fortin 1995). Bottazzi (2004) finds significant effects of the mortgage qualification constraint on female labor market participation in Britain, while Del Boca and Lusardi (2003) find similarly strong effects of mortgages on women's labor market participation in Italy. A more recent study by Rossi and Trucchi (2012), which uses various definitions of liquidity constraints, also finds significant impacts of credit rationing on actual and desired labor supply in Italian households. Belkar, Cockerell, and Edwards (2007) use data from the Household, Income and Labour Dynamics in Australia survey and find the strongest effect of indebtedness on individual's likelihood of labor force participation when using a debt-servicing ratio variable. In addition, the effects are larger for women than for men, and larger for women with young children than for those without. The authors suggest that this ordering reflects each group's relative attachment to the labor force.

This paper builds on the previous literature by examining the effect of liquidity constraints on labor supply and Social Security benefit receipt using data from the Health and Retirement Study and focusing on households who are of Social Security eligibility age. With a 
simple conceptual framework, we show that early Social Security claiming provides older adults who are liquidity constrained with an additional income source for achieving better consumption smoothing. A testable implication of our simple model is that an individual's decision to work more, claim benefits early, or both is a function of the borrowing limit and how binding the constraint is, among other factors.

\section{Conceptual Framework}

For simplicity, we assume a two-period framework in which people work in the first period and are retired in the second. They derive utility from consumption and leisure. In the first period they choose their levels of both consumption and leisure, while in the second period they choose only their level of consumption (since they are retired and leisure is fixed). Individuals maximize their utility (U) over the two periods by choosing optimal leisure (l) and consumption (c) subject to a budget constraint. The utility function can be expressed by the following equation:

$$
U=\sum_{t=1}^{2} \beta^{t-1} u\left(c_{t}, l_{t}\right)=u\left(c_{1}, l_{1}\right)+\beta u\left(c_{2}, 1\right)
$$

where $u^{\prime}>0, u^{\prime \prime}<0$ and $u_{c, l}>0$.

We further assume individuals have no initial assets or bequests, so their budget constraints can be expressed as:

$$
\begin{aligned}
& w\left(1-l_{1}\right)-A_{1}=c_{1} \\
& A_{1}(1+r)+Y_{r}=c_{2}
\end{aligned}
$$

or

$$
w\left(1-l_{1}\right)(1+r)+Y_{r}=c_{1}(1+r)+c_{2}
$$

where $w$ is the wage rate, $A_{l}$ is personal savings at end of the of the first period, $r$ is the interest rate, and $Y_{r}$ is retirement income from Social Security benefits. Individuals choose their optimal consumption and leisure in the first period, and devote all their time to leisure in the second period while consuming all remaining income, given the choices they made in the first period:

$$
\max _{c_{1}, l_{1}} u\left(c_{1}, l_{1}\right)+\beta u\left(w\left(1-l_{1}\right)(1+r)+Y_{r}-c_{1}(1+r), 1\right)
$$


Without market imperfections, optimal consumption and leisure satisfy the following first order conditions:

1) consumption: $u_{c}^{\prime}\left(c_{1}^{*}, l_{1}^{*}\right)-\beta(1+r) u_{c}^{\prime}\left(c_{2}^{*}, 1\right)=0$ or $\frac{u_{c}^{\prime}\left(c_{1}^{*}, l_{1}^{*}\right)}{u_{c}^{\prime}\left(c_{2}^{*}, 1\right)}=\beta(1+r)$

2) leisure: $\quad u_{l}^{\prime}\left(c_{1}^{*}, l_{1}^{*}\right)-\beta(1+r) w u_{c}^{\prime}\left(c_{2}^{*}, 1\right)=0$ or $\frac{u_{l}^{\prime}\left(c_{1}^{*}, l_{1}^{*}\right)}{u_{c}^{\prime}\left(c_{1}^{*}, 1\right)}=w \beta(1+r)$

These equations imply that the agent will try to equate the marginal utility of consumption across periods, as well as the marginal utility of consumption and leisure in the first period.

\section{Borrowing Constraints}

Next, assume that there are liquidity constraints, limiting agents to borrowing below a certain threshold $A_{1} \geq B$. The Kuhn-Tucker theorem allows us to rewrite the maximization problem in the following way:

$$
\max _{c_{1}, l_{1}} u\left(c_{1}, l_{1}\right)+\beta u\left(w\left(1-l_{1}\right)(1+r)+Y_{r}-c_{1}(1+r), 1\right)+\lambda\left(w\left(1-l_{1}\right)-c_{1}-B\right)
$$

And maximization needs to satisfy the following conditions:

$u_{c}^{\prime}\left(c_{1}^{*}, l_{1}^{*}\right)-\beta(1+r) u_{c}^{\prime}\left(c_{2}^{*}, 1\right)-\lambda^{*}=0$

$u_{l}^{\prime}\left(c_{1}^{*}, l_{1}^{*}\right)-\beta(1+r) w u_{c}^{\prime}\left(c_{2}^{*}, 1\right)-\lambda^{*} w=0$

$\lambda^{*}\left(w\left(1-l_{1}\right)-c_{1}-B\right)=0$

We know that the Lagrange multiplier must be non-negative: $\lambda^{*} \geq 0$. When the constraint is not binding or $\left.\left(w\left(1-l_{1}\right)-c_{1}-B\right)>0\right)$, then $\lambda^{*}=0$ and the problem reverts back to the unconstrained case we discussed above. If $\lambda^{*}>0$ then the constraint must bind. From the first order condition we see that

$u_{c}^{\prime}\left(c_{1}^{C}, l_{1}^{C}\right)-\beta(1+r) u_{c}^{\prime}\left(c_{2}^{C}, 1\right)=\lambda^{*}>0$ 
Hence $u_{c}^{\prime}\left(c_{1}^{C}, l_{1}^{C}\right)>\beta(1+r) u_{c}^{\prime}\left(c_{2}^{C}, 1\right)$, meaning that the agent's marginal utility of consumption in the first period will be higher than the discounted marginal utility of consumption in the second period. It also suggests that optimal consumption in the first period will be lower and optimal consumption in the second period will be higher than in the unconstrained case.

Thus, the level of leisure in first period that was optimal under the unconstrained case will no longer be optimal when the constraint binds because the marginal utility of leisure will no longer equal that of consumption. Since consumption in the first period is lower in this case, the marginal utility is higher. To set the intra-period marginal utilities of consumption and leisure equal to each other, the agent has only one option and that is to increase the marginal utility of leisure via increasing his labor supply in the first period. ${ }^{1}$

See figure 1 for a graphical representation. In the presence of binding borrowing constraints, the agent's consumption bundle — consumption in the first and second periodmoves from point A to point C. Point B would have been the resulting bundle had labor supply not been adjusted. The agent is able to improve his well-being by moving from point B to point $\mathrm{C}$ and adjusting his labor supply in the first period. Still, due to the borrowing constraints, he ends up on a lower indifference curve $\mathrm{U}_{3}$ compared with $\mathrm{U}_{1}$ which was feasible in the absence of borrowing constraints.

\section{Borrowing Constraints and Early Claiming}

Let's further introduce the option of early Social Security claiming, which in the context of this simplified model makes some of the retirement income available in period 1. Let's assume that if early claiming is chosen, half of the retirement income can be used in period 1 and the rest in period 2. In addition, since early claiming results in actuarially reduced benefits, assume that only a portion $(1-\propto)$, where $0<\propto<1$, of the full retirement income $Y_{r}$ is available to the agent overall if he starts benefits early. Now the agent's utility maximization problem involves one more choice $\mathrm{D}=1$ if he chooses early claiming, and $\mathrm{D}=0$ otherwise.

$$
\max _{c_{1}, l_{1}, D} \sum_{t=1}^{2} \beta^{t-1} u\left(c_{t}, l_{t}\right)=u\left(c_{1}, l_{1}\right)+\beta u\left(c_{2}, 1\right)
$$

subject to

\footnotetext{
${ }^{1}$ Since $u_{c}^{\prime}\left(c_{1}^{C}, l_{1}^{U}\right)<u_{c}^{\prime}\left(c_{1}^{U}, l_{1}^{U}\right)$, the only way to make sure $u_{l}^{\prime}\left(c_{1}^{C}, l_{1}^{C}\right)=\beta(1+r) w u_{c}^{\prime}\left(c_{1}^{C}, l_{1}^{C}\right)$ is to set $l_{1}^{C}<l_{1}^{U}$.
} 


$$
\begin{gathered}
w\left(1-l_{1}\right)+D \frac{(1-\propto \mathrm{D}) Y_{r}}{2}-A_{1}=c_{1} \\
A_{1}(1+r)+(2-D) \frac{(1-\propto \mathrm{D}) Y_{r}}{2}=c_{2}
\end{gathered}
$$

Or the budget constraint can be expressed as:

$$
w\left(1-l_{1}\right)(1+r)+\frac{r(1-\propto \mathrm{D}) Y_{r}}{2}+(1-\propto D) Y_{r}=c_{1}(1+r)+c_{2}
$$

In the absence of borrowing constraints, the agent would never choose $\mathrm{D}=1$ as that will bring his budget constrain down, and he could always improve on his position and move to a higher indifference curve by choosing $\mathrm{D}=0$ (figure 1 ).

However, when borrowing constraints $A_{1} \geq B$ are present and binding, as we saw in the example above, inter-period marginal utility of consumption is not equated. The option of early claiming provides the agent with one additional tool besides adjusting labor supply, which he can use to ease up the borrowing constraints and move to a higher indifference curve. As figure 1 shows, depending on the magnitude of the actuarial reduction $\propto$, the individual might be tempted to choose early claiming and consumption allocation at point $\mathrm{D}$, as it results in higher lifetime utility. Notice that allocation $\mathrm{D}$ is on a higher indifference curve than point $\mathrm{C}$ - the optimal allocation under borrowing constraints and no availability of early claiming. Also importantly, when the constraint is binding both $l_{1}^{*}$ and $D^{*}$ are a function of the borrowing limit $B$.

There is one important caveat to our simple analysis. We implicitly assumed that receiving early Social Security benefits is a possibility, while maintaining the unconstrained level of leisure/labor. In practice, for individuals below the full retirement age, Social Security withholds benefits if annual earnings exceed a certain level. ${ }^{2}$ This scenario is not shown on figure 1. The effect of it can be visualized as shifting the budget constraint under early claiming down, if the agent needs to reduce hours to keep the benefit. Alternatively, if the agent's labor supply is below the exempt amount, he will not be affected by the earnings test, and can even increase his labor supply and shift the budget constraint up. As a result, the best allocation under early claiming might be better or worse than allocation $\mathrm{D}$, depending on how close the

\footnotetext{
${ }^{2}$ This level, the retirement earnings test exempt amount, equaled \$15,120 in 2013.
} 
individual's earnings are to the earnings test threshold. Overall both increased labor supply and early benefit claiming, individually or in combination, are potential responses to the existence of borrowing constraints and present an interesting empirical question.

Whether individuals tap into their Social Security benefits early as a way to ease any borrowing constraints is a question whose answer also has important policy implications. The Social Security program was not designed to address any credit or insurance market failures. It matters when a worker starts his benefits for a number of reasons. First, the notion that the present value of Social Security benefits for an individual worker is the same no matter what age between 62 and 70 he starts them is only true for the worker with the average life expectancy, and only when spousal and survivor benefits are ignored. Second, the value of Social Security goes beyond its expected present discounted value. Adding to the calculation the insurance that Social Security provides to workers and their survivors against outliving resources shows that delaying claiming can be welfare improving for many households (Sun and Webb 2009). In an environment of increasing household indebtedness, any distorting effects that debt in retirement might have, via borrowing constraints or other channels, on labor supply and Social Security claiming, need to be better understood as they have the potential to significantly impact retirement income security of both current and future retirees.

The simple conceptual framework presented above provides us with the following testable implications: the more binding the liquidity constraints, the higher the agent's incentive to either increase work, claim Social Security early, or both. Which of these routes an individual chooses is a function of many factors, including: how binding the borrowing constraints are, the relative magnitude of wages versus potential Social Security income, the size of the actuarial reduction for claiming early benefits, and whether and how much earnings are limited by the retirement earnings test. ${ }^{3}$

In the conceptual framework presented so far, the individual optimizes over hours of work, consumption and benefit claiming. However, our empirical specification models labor force participation, that is the effect of borrowing constraints on the extensive rather than intensive margin of labor supply. Since the conceptual model is presented for illustrative purposes, a discussion of an interior solution discussion makes it more easily tractable. Although the empirical estimation will not model hours of work, we interpret a potential significant effect

\footnotetext{
${ }^{3}$ The annual earnings test was repealed in 2000 for workers past their full retirement age.
} 
of our debt measure on the participation decision as evidence of the distorting effects of debt on labor supply. ${ }^{4}$

\section{Empirical Strategy}

Our goal is to estimate the influence of debt on labor supply and Social Security benefit receipt. To do this, we estimate several different model specifications. We begin with a set of latent variable models in the form of bivariate probits of labor supply and Social Security receipt. We then estimate nonparametric survival and hazard functions of the probability of retiring and the probability of claiming Social Security benefits. We estimate these separately for older adults with and without debt to better capture how the timing of full retirement and Social Security claiming might be related to having debt. Finally, we estimate discrete-time hazard models of the influence of debt on the timing of initial Social Security benefit claiming and the timing of full withdrawal from the labor force.

It is worth noting that absent data on individuals' ability to obtain loans, our measures are at best only proxies for borrowing constraints. Our assumption is that individuals and households with outstanding debt, those with higher levels of debt, or higher debt-to-asset and debt-to-income ratios are more likely to be liquidity constrained than those who are debt free. However, we cannot rule out the possibility that any observed effects of debt are due to other channels or mechanisms. For example, higher labor force participation among those with debt might be driven by negative wealth shocks from the past and thus be the result of a wealth effect forcing individuals to consume less leisure and goods. However, because the wealth and liquidity effects work in opposite directions with respect to early benefit claiming, finding a positive effect of debt on early claiming will provide us with stronger evidence for the presence of liquidity constraints.

\section{Bivariate Probit Models}

We start by estimating latent variable models of labor force participation and Social Security receipt. The propensity to participate in the labor force or to collect Social Security benefits is modeled as a function of personal demographic and socio-economic characteristics $X$ and liquidity constraints $L c$.

\footnotetext{
${ }^{4}$ See the appendix for a graphical illustration of how borrowing constraints can impact both the intensive and extensive margins of labor supply.
} 


$$
\begin{gathered}
y_{i}^{*}=X_{i} \beta+L c_{i} \gamma+\varepsilon_{i} \\
y_{i}=1\left[y_{i}^{*}>0\right]
\end{gathered}
$$

More specifically, to allow for potential correlation between the two decisions, we model the two equations jointly in a bivariate probit model, as follows:

$$
\begin{aligned}
& y_{1 i}^{*}=X_{i} \beta+L c_{i} \gamma+\varepsilon_{1 i} \text { where } \varepsilon_{1 i} \sim \mathcal{N}\left(0, \sigma^{2}{ }_{1}\right) \\
& y_{2 i}^{*}=X_{i} \beta+L c_{i} \gamma+\varepsilon_{2 i} \text { where } \varepsilon_{2 i} \sim \mathcal{N}\left(0, \sigma^{2}{ }_{2}\right)
\end{aligned}
$$

where $y_{1 i}^{*}$ and $y_{2 i}^{*}$ are two latent variables observed according to the following rule: $y_{1 i}=$ $1\left[y_{1 i}^{*}>0\right]$ and $y_{2 i}=1\left[y_{2 i}^{*}>0\right]$, the error terms are assumed to be independently and identically distributed as bivariate normal, and $\rho$ is the correlation parameter.

$$
\left[\begin{array}{l}
\varepsilon_{1} \\
\varepsilon_{2}
\end{array}\right] \sim \mathcal{N}\left[\left[\begin{array}{l}
0 \\
0
\end{array}\right],\left[\begin{array}{cc}
1 & \sigma_{12} \\
\sigma_{12} & \sigma_{2}^{2}
\end{array}\right]\right] \quad \text { or } \quad\left[\begin{array}{l}
\varepsilon_{1} \\
\varepsilon_{2}
\end{array}\right] \sim \mathcal{N}\left[\left[\begin{array}{l}
0 \\
0
\end{array}\right],\left[\begin{array}{ll}
1 & \rho \\
\rho & 1
\end{array}\right]\right]
$$

\section{Survival Analyses}

To capture the effect of debt and liquidity constraints on individuals' timing of labor force retirement and Social Security claiming, we estimate a set of duration models. In one model, we observe spells for each person beginning when he turns age 62 and ending when he fully retires, drops out of the survey, or reaches age 69 without retiring. In another model, we observe spells for each person beginning when he turns age 62 and ending when he starts collecting Social Security benefits, drops out of the survey, or reaches age 69 without claiming benefits.

We begin by plotting the cumulative probability of not yet retiring. The retirement hazard, $\lambda(t)$, is the probability of retiring at age $t$, conditional on not having already retired. The survival function at age $t, \mathrm{~S}(t)$, is defined as

$$
\mathrm{S}(t)=\mathrm{S}(t-1) *[1-\lambda(t)],
$$

and shows the probability of not having retired by age $t$. We estimate $\mathrm{S}(\mathrm{t})$ using the nonparametric Kaplan-Meier estimator. Since, at this point, we are only interested in the shape 
of the raw (unconditional) survival data, we estimate $\mathrm{S}(\mathrm{t})$ without any regressors. Similarly, we estimate a survival curve that indicates the duration until initial benefit claiming. We compare survival curves for those with and without debt at age 62.

Next, we estimate discrete-time multivariate hazard models where the hazard rate is a function of personal demographic and socio-economic characteristics $X$, liquidity constraints $L c$, and the elapsed time since the beginning of the spell. ${ }^{5}$ We assume a logistic functional form ${ }^{6}$ for the hazard function, $\lambda_{i k}=\frac{e^{X_{i k} \beta+L c_{i} \gamma}}{1+e^{X_{i k} \beta+L c_{i} \gamma}}$, which allows us to estimate the model as a logit model via maximum likelihood. ${ }^{7}$ The dependent variable equals 1 in the period when the individual fully retires or starts collecting benefits; otherwise, it equals zero.

\section{Alternative Specifications}

To address potential unobserved heterogeneity, we estimate random effects models utilizing the panel nature of our data. The equations we estimate belong to the class of discrete choice panel data models with individual-specific effects, and take the following form:

$$
\operatorname{Pr}\left[y_{i t}=1 \mid \mathrm{X}_{i t}, L c_{i t}, \alpha_{i}\right]=\Phi\left(\alpha_{i}+X_{i t} \beta+L c_{i t} \gamma\right)
$$

where $\Phi(\cdot)$ is the standard normal cumulative distribution function (cdf). The unobserved individual-specific permanent characteristics $\alpha_{i}$ could include unobserved risk preferences or attitudes towards work and leisure. ${ }^{8}$ We use a probit specification, which assumes that the individual effects are normally distributed.

In the prior specifications, we assumed that $L c$ was exogenous; however, there are many reasons to think that having debt or being liquidity constrained is not strictly exogenous. For example, causality might go in the opposite direction. That would be true if individuals who

\footnotetext{
${ }^{5}$ Given the biennial nature of our data, observations are in two-year periods. The MLE approach takes care of the potential problems with right censoring. Each censored spell contributes to the likelihood with the discrete survival function, so we are acquiring the maximum information from people who were censored by utilizing the fact that they survived until the time of the censoring. As for the completed spells, they contribute to the likelihood with the discrete time density function.

${ }^{6}$ We also estimate a clog-log specification which has an analogous proportional hazards assumption as a continuous-time Cox model. The results are consistent with the logit specification and are available upon request.

${ }^{7}$ Note that this model does not allow for unobserved heterogeneity.

${ }^{8}$ One could potentially specify a fixed-effects logit model, and estimate it via conditional maximum likelihood. However, that specification does not recover the coefficients on time-invariant variables. See Cameron and Trivedi (2005) for discussion.
} 
have higher preferences for leisure are also be more likely to be liquidity constrained, or if individuals who do not work are less likely to take out a mortgage. To address such endogeneity problems, we estimate two sets of models that differ in whether the instrumented variable is dichotomous or continuous.

First, we estimate jointly the latent variable model of our outcome variable (work or benefit receipt) with a latent variable model that determines the presence of liquidity constraints. For this exercise, we consider only mortgages (and not other forms of debt). Thus we estimate a two equation system, where $y_{i}^{*}$ and $L c_{i}^{*}$ are latent variables:

$$
\begin{aligned}
& y_{i}^{*}=X_{i} \beta+L c_{i} \gamma+u_{i} \\
& L c_{i}^{*}=X_{i} \delta+Z_{i} \theta+\epsilon_{i}
\end{aligned}
$$

This specification was first proposed by Heckman (1978) and was also applied in Del Boca and Lusardi (2003) to instrument the effect of the propensity to hold a mortgage on female labor supply in Italy. We assume a joint normal distribution for the two error terms.

To deal with a continuous endogenous $L c$ variable, such as the dollar value of the debt, we apply a control function approach where equation (8.2) is replaced by equation (8.3):

$$
L c_{i}=X_{i} \delta+Z_{i} \theta+\varepsilon_{i}
$$

In general, control function estimators work by estimating a model of endogenous regressors as a function of instruments (equation 8.3), much like the 'first stage' of a two-stage least squares estimation, and then using the estimates of the errors from this model as additional "control variable" regressors in the binary choice model (equation 8.2). The significance of the "control variables" provides a test for the endogeneity of the regressor $L c .{ }^{9}$

Identifying the direction of causality, in both specifications, requires factors that shift the likelihood of facing a liquidity constraint but that are not directly related to the propensity to work or to claim benefits. Appropriate instruments $Z$ would be, for example, those that capture the conditions of the housing market.

\footnotetext{
${ }^{9}$ See Wooldridge (2002).
} 
Finally, we apply a difference-in-differences approach to the duration model presented above to better isolate the effect of debt on the delaying retirement and benefit claiming using a plausibly exogenous employment shock variation. We model the hazard function in the following way:

$$
\lambda_{i k}=\frac{e^{X_{i k} \beta+L c_{i} \gamma_{1}+I\left(\mathrm{Jobloss}_{i}=1\right) \gamma_{2}+L c_{i}{ }^{*} I\left(\mathrm{Jobloss}_{i}=1\right) \gamma_{3}}}{1+e^{X_{i k} \beta+L c_{i} \gamma_{1}+I\left(\mathrm{Jobloss}_{i}=1\right) \gamma_{2}+L c_{i}^{*} I\left(\mathrm{Jobloss}_{i}=1\right) \gamma_{3}}}
$$

where the coefficient $\gamma_{3}$ on the interaction term captures the incremental effect of having debt on retirement and claiming. The variation in behavioral responses to an exogenous employment shock between individuals who are potentially more liquidity constrained (those with debt) and those who are less liquidity constrained (no outstanding debt) allows us to better capture the causal impact of debt.

\section{Data and Sample}

Our analysis is based on the Health and Retirement Study (HRS), a large nationally representative survey of Americans age 51 and older that has been interviewing respondents every other year since 1992. We restrict our sample to non-disabled individuals ages 62 to 69 because they are age-eligible to collect Social Security retired worker benefits.I

In addition to detailed information on personal characteristics, employment, earnings, income, and program participation, the HRS provides valuable information on financial assets, housing wealth, mortgage debt, credit card balances, and other debt. We use several measures to gauge older adults' indebtedness, including whether or not they hold any debt, their level of debt, their debt-to-income ratio, and their debt-to-asset ratio. We use the debt-to-income ratio to capture short-term liquidity constraints and the debt-to-asset ratio to capture long-term liquidity constraints. We also consider various sources of debt—mortgage, credit card, or other-for each of these measures. Mortgage debt is the outstanding mortgage on the primary residence, credit card debt refers to credit card balances carried over from one month to the next, and other debt includes the outstanding mortgage on a secondary residence, unpaid medical bills, life insurance policy loans, and loans from relatives. In 2008, the HRS added a separate question about credit card debt. Prior to 2008, the survey did not distinguish credit card debt from other debt. 
The predictors in our multivariate models include the debt variables described above, as well as sex, age, race and ethnicity, education, cohabiting status, spouse's earnings and claiming status, self-reported health, and census region of residence. We also control for whether the respondent's age is above his Social Security FRA, since the retirement earnings test does not apply after the FRA - meaning that the respondent could claim his benefit and continue to work without any penalty. In addition, we control for other household income, which we define as total household income excluding the respondent's earnings and Social Security benefits. Finally, we control for financial assets (including checking and savings accounts, certificates of deposit, stocks, bonds, IRAs, and other financial assets) and non-financial or other assets (including real estate, vehicles, and businesses).

The dependent variables in our multivariate models relate to work and Social Security benefits. In the bivariate probit models, they capture whether the respondent is currently working for pay and whether the respondent currently receives Social Security benefits. In the duration models, they capture the age the respondent fully retires and the self-reported age that the respondent first claims benefits (or the age at the time of the interview when he first reports receiving positive benefits if the self-reported age is missing).

\section{Descriptive Analyses}

Americans are increasingly likely to have debt at older ages. Between 1998 and 2010, the share of adults ages 62 to 69 with any type of debt increased from 47.9 to 62.3 percent. Moreover, the median value of outstanding debt for those with debt grew 68 percent over the same period-from $\$ 19,020$ per person in 1998 to $\$ 32,130$ per person in 2010 (figure 2).

Mortgages are the most significant source of debt - accounting for slightly more than half the debt of indebted individuals in this age group. Although that share has remained relatively constant since 1998, the proportion of adults with a mortgage has increased considerably over time (figure 3). Less than a third of adults ages 62 to 69 had a mortgage in 1998, compared with about two-fifths in 2010. Except for a slight dip due to the Great Recession, the median value of outstanding mortgages, among those with mortgages, has also been on the rise-increasing 60 percent since the late 1990s. This dramatic rise over time in both the prevalence and value of mortgages corresponds with the decline between 1998 and 2010 in the share of the home owned 
(figure 4). Finally, among homeowners with mortgages, their mortgage constitutes almost all their debt (roughly 90 percent) — a share that has remained constant over the period.

While the trends in mortgage debt follow closely the trends in total debt, they are not the sole driver of increasing indebtedness among older adults. Figure 5 shows that the share of adults age 62 to 69 with other debt has been also on the rise-from 31.5 percent in 1998 to 44.5 percent in 2010. The median value of other debt, however, does not exhibit the same marked rise over time as mortgage debt.

To get a better picture of older adults' overall financial position, we also tracked how their average debt-to-asset ratio has changed over time (figure 6). Although older adults became more leveraged during the Great Recession, an increasing trend in indebtedness was evident even before the financial downturn of 2008. On average, debt consumed 9.9 percent of older adults' assets in 1998, 13.9 percent in 2006, and 17.9 percent in 2010.

Moreover, the increased trend in indebtedness has impacted both individuals who have not reached full retirement age, as well as those who have. Figure 7 shows age differences in the share of older adults with any debt, and figure 8 shows age differences in the share of older adults with mortgages. The prevalence of both total debt and mortgage debt has increased dramatically between 1998 and 2010 for all age groups, suggesting that the increased trend in indebtedness is not a phenomenon affecting only relatively young households.

Furthermore, the rise in indebtedness among older adults is not a trend observed among only high-income individuals. Although high-income adults are more likely to have outstanding debt, the prevalence of debt has been increasing for all income terciles. Between 1998 and 2010, the share of older adults with debt increased 13 percentage points for those at the top, 17 percentage points for those in the middle, and 14 percentage points for those at the bottom tercile of income (figure 9). Similarly, over the last twelve years, the share of older adults with outstanding mortgages rose 15 percentage points for those at the top, 14 percentage points for those in the middle, and 5 percentage points for those at the bottom (figure 10).

Our simple conceptual framework, presented earlier, suggested that older adults have two possible responses to debt - they either delay retirement or they tap into their Social Security wealth, perhaps prematurely. While it's expected that labor force participation declines as people age and Social Security receipt increases with age, there are striking differences between those with and without debt. Older adults with debt are significantly more likely to work and 
significantly less likely to receive Social Security benefits than their counterparts without debt (table 1). Nearly half of adults ages 62 to 69 with any debt work, compared with only a third of older adults without debt. On the flip side, only 71 percent of older adults with debt receive Social Security benefits, compared with 78 percent of those without debt. The differences between those with and without debt are especially noticeable through age 65 . Past age 65 , there continues to be differences in labor force participation by indebtedness, but the differences in benefit receipt disappear. This finding suggests that older adults' behavior is influenced by the Social Security retirement earnings test—which does not apply after FRA. Finally, differences in labor force participation and benefit receipt are similar, but larger, between those with and without mortgage debt, and similar, but smaller, between those with and without credit card debt.

\section{Multivariate Analyses}

Next we consider how debt influences older adults' labor supply and benefit receipt controlling for other factors. The bivariate probit coefficients have the expected signs and significance with respect to most variables in our model —age, education, health, and spouse's work and benefit receipt (see table A1 for the full set of results). Table 2 shows the marginal effects of the debt variables on labor force participation and benefit receipt.

Even controlling for other factors, we find that having debt, as well as the dollar value of debt, is positively and significantly correlated with individuals' propensity to work and negatively and significantly correlated with their likelihood of receiving Social Security benefits. In particular, those with debt are 8 percentage points more likely to work and 2 percentage points less likely to receive benefits compared with those without debt (model 1). In addition, the amount of debt also has a statistically significant impact on older adults' behavior; an increase of $\$ 10,000$ in debt per person increases the likelihood of working by 0.7 percentage points and reduces the likelihood of receiving benefits by 0.3 percentage points (model 4).

Among the sources of debt, mortgage debt consistently has a stronger impact on labor supply and Social Security receipt than do credit card balances or other debt. Having a mortgage increases the likelihood of working by about 7 percentage points and reduces the probability of receiving Social Security benefits by 3 percentage points (model 2). Having other debt, outside of housing debt, also has a significant impact on older adults' labor force participation, raising their probability of working by 5.7 percentage points. However, the effect of other debt may be driven by credit card debt. Separate from other debt, unpaid credit card balances appear to 
significantly raise the probability of working by 4 percentage points, while other debt is no longer statistically significant (model 3). While the existence of mortgage debt negatively impacts the likelihood of receiving benefits, having credit card or other debt does not (models 2 and 3$).^{10}$

Interestingly, the amount of debt impacts older adults differently depending on the type of debt. Whereas an additional $\$ 10,000$ in housing debt increases the chances of working by 0.5 percentage points, the same amount of debt in the form of credit card balances seems to increase the likelihood of working by 11 percentage points (model 6). Similarly, the value of credit card debt appears to have a stronger impact on the propensity to receive benefits than does the value of mortgage debt. An increase of $\$ 10,000$ in credit card debt per person seems to lower the likelihood of benefit receipt by 12 percentage points, compared with only 0.2 percentage points for mortgage debt (model 6). Because of data limitations, we should be cautious about overstating the credit card results. First, the credit card sample is significantly smaller than our main model sample. Second, the credit card results are based on only two periods of data since credit card information was collected starting in 2008. In contrast, our main model results are based on 10 periods of data. Finally, the two periods of credit card data, 2008 and 2010, coincide with the recent recession.

Focusing solely on the sample of homeowners reveals somewhat larger effects for mortgage debt (table 3). ${ }^{11}$ Among homeowners, those with an outstanding mortgage are 8 percentage points more likely to work and 4 percentage points less likely to receive benefits (model 1). Table 3 also shows the effect of two additional proxies of liquidity constraint: the ratio of the value of debt to assets (long-term liquidity constraint/leverage ratio), and the ratio of debt to other household income (short-term liquidity constraint/leverage ratio), where both are expressed in percentage terms. Whereas the short- and long- term measures of the mortgage leverage ratio have the same impact on benefit receipt, reducing the likelihood by 0.04 percentage points, the long-term ratio increases the probability of working more than the shortterm ratio- 0.10 versus .04 percentage points (models 3 and 4).

\footnotetext{
${ }^{10}$ We performed several tests for differences in the effects of having a mortgage or other debt on labor supply and benefit receipt by sex, marital status, and wealth. We find that having a mortgage has a slightly stronger impact on labor force participation for women than for men. However, we find no statistically different effects by marital status or wealth.

${ }^{11}$ Nearly 90 percent of individuals in our HRS sample are homeowners.
} 
The next set of results show that those with outstanding debt are also more likely to delay fully retiring from the labor force and to postpone claiming Social Security benefits. We begin with a descriptive analysis of the duration (survival function) until full retirement and the duration until starting Social Security benefits, using a non-parametric Kaplan-Meier estimator. Of particular interest is the extent to which these durations differ by indebtedness. ${ }^{12}$

As expected, the probability of not having fully retired (i.e. working) declines precipitously with age - from over 90 percent at age 62 to about 20 percent at age 69 (figure 11). However, older adults with debt at age 62 (the beginning of their spell) are more likely to delay retirement than their counterparts without debt. The difference between the two groups is even more striking when considering mortgage debt (figure 12). Close to 65 percent of homeowners with mortgages are still working at age 64, compared with only 54 percent of those without mortgages.

As is well known, the probability of delaying Social Security benefits also declines with age (figure 13). As previous literature has documented, the survival function declines rapidly between ages 62 and 65. Interestingly, individuals who have debt at age 62 (the beginning of their spell) are significantly more likely to postpone claiming benefits, particularly before age 65 . Again, the difference between the two groups is even more striking when considering mortgage debt (figure 14). Whereas close to 50 percent of homeowners with mortgages still have not claimed benefits by age 65 , only 35 percent of those without mortgages have delayed claiming.

The Kaplan-Meier estimator, however, does not account for other potential factors affecting retirement and claiming. To control for those, we estimate the discrete-time hazard models described earlier and present odds ratios, which show relative probabilities, for the main debt variables (table 4). ${ }^{13}$ We find that, controlling for other factors, having debt reduces the relative probability of fully retiring by approximately 22 percent $^{14}$, and the relative probability of claiming Social Security benefits by 14 percent (model 1). Both mortgage debt and other debt have a negative and statistically significant impact on both labor force retirement and benefit claiming (model 2). Finally, the amount of mortgage debt also reduces the likelihood of fully retiring, as well as the probability of claiming Social Security benefits (model 4).

\footnotetext{
${ }^{12}$ For the Kaplan-Meier estimation, having debt is determined at the beginning of the spell.

${ }^{13}$ For conciseness, we do not present the full set of coefficient estimates, which are consistent in direction and significance with the bivariate probit results. They are, however, available from authors upon request.

${ }^{14}$ Computed as 1-0.7756.
} 
Endogeneity Concerns and Instrumental Variables Approach. Up to this point in the estimation we assumed the explanatory variables were strictly exogenous. It is possible, however, that the variables indicating liquidity constraints are endogenous. This could be due to reverse causality, such as labor force participation and benefit receipt today affect having a mortgage or other debt in the future. We address this issue by estimating the set of instrumental variable models outlined earlier. As mentioned, viable instruments are those that capture household's access to credit, but are not related to their work and benefit receipt decisions.

We focus on instrumenting the mortgage constraints, instead of total debt or credit card debt, for two reasons: First, the results so far have shown that this category of debt consistently has the strongest impact on individuals' work and claiming decisions. Second, although credit card debt seems to also have a strong influence, the HRS lacks the information required to identify individuals who have easier access to credit compared with those who do not. ${ }^{15}$

We matched our HRS sample with data from the Federal Housing Finance Agency to capture variation over time and census regions in the state of the housing markets. In particular we used as instruments the average effective interest rates, term to maturity and loan-to-price ratio on conventional single-family mortgages, and the share of adjustable rate loans. ${ }^{16}$

Tables 5 and 6 present the results of the IV framework on work and benefit receipt respectively. Column 1 shows coefficient estimates from the models that instrument the binary variable of having a mortgage and column 2 shows coefficients from the models that instrument the per person value of the mortgage. The estimated coefficients on the mortgage variables retain their expected direction from former specifications, but lose their significance- except for the effect of having a mortgage on work, which continues to be strong and highly significant. Overall, the instruments seem to be strong determinants of the probability of having a mortgage and the dollar value of the mortgage. However, the Wald test of exogeneity cannot reject the null hypothesis of no endogeneity in any of the models.

\footnotetext{
${ }^{15}$ Potential variables related to credit card constraints would be, for example, the credit score, information on whether the individual has been declined credit cards, or information on how often he applies for credit cards. With respect to having a mortgage, potential instruments include the credit score, the characteristics of the mortgage contract, and information collected on the mortgage application.

${ }^{16}$ While the Federal Housing Agency data is on a state level, the public version of the HRS data does not include state identifiers. Instead we aggregated the data on a census division-year basis, using the relative state population as weights.
} 
Accounting for Individual Effects. As a robustness check we also estimated a set of random effects probit models to allow for unobserved heterogeneity in the form of individualspecific effects. Marginal effects of the debt variables on work and benefit receipt are presented in table 7. Results are consistent with earlier findings. Mortgages and other debt are both significant positive determinants of work. Having a mortgage has a negative statistically significant impact on benefit receipt, whereas the relationship between other debt and benefit receipt is not significantly different from zero.

Gender Differences. To account for potential differences in their behavioral responses, we estimated bivariate probit models of work and benefit receipt separately for men and women (table 8). We find that the impact of debt on work is similar in magnitude and direction for both men and women. However, the effect of debt on Social Security claiming is driven predominantly by men and is often insignificant for women.

\section{Estimating the Impact of Debt in the Event of Unexpected Shocks}

Next, to better capture the causal effect of debt on retirement timing and Social Security claiming, we estimated the discrete-time hazard models on the sample of homeowners using a difference-in-differences specification as shown in equation (9). The results show differences between indebted adults and those who are debt-free in their response to an unexpected household employment shock, while also controlling for total outstanding debt, total assets, and the other variables presented in table 4 . The intuition is that homeowners with mortgages have effectively less liquid wealth than homeowners without mortgages and are more likely to be constrained or become constrained in the presence of a job loss.

We classify adults as experiencing a household employment shock if the respondent or spouse reports being fired, laid off, or terminated because the business closed. ${ }^{17}$ As a proxy for liquidity constraints, we use a dichotomous variable indicating whether the household has an outstanding mortgage at the beginning of the spell. Prompted by the gender differences we observed in the previous model, we estimated the hazard models on men and women separately.

The results show that both men and women are more likely to retire, and men are more likely to claim benefits after experiencing a household employment shock (table 9). Compared

\footnotetext{
${ }^{17} \mathrm{We}$ assume the shock has permanent effects in all periods following the job loss.
} 
with male homeowners without mortgage debt, those with outstanding mortgages are 43 percent less likely to fully retire and 44 percent less likely to claim benefits when faced with an involuntary job loss. Similar to earlier results, we find no evidence that having debt results in earlier retirement or earlier benefit claiming. Additionally, our results suggest that mortgage constraints might have the opposite effect on women than they do on men; however, the coefficients are not significant at standard significance levels. Possible explanations for the differences between men and women are that: 1) women tend to have more sporadic employment patterns and their retirement tends to coincide with their husbands' retirement; and 2) data restrictions do not allow us to properly control for eligibility of Social Security retired worker benefits based on women's own earnings records. Access to data with information on benefit eligibility and possibly administrative earnings histories would enable us to better test the effect of liquidity constraints on women's claiming behavior.

\section{Discussion}

Over time, Americans have become more accepting of debt. The proliferation of credit cards in 1980s and 1990s and subprime mortgages in the early 2000s were key drivers in this transformation of attitudes. Obtaining credit and loans became easier, relatively inexpensive, and more acceptable. As a result, the United States has become an indebted society. Especially concerning, however, is not the rise in the level of debt, but the rise in the share of highly leveraged Americans.

Also concerning is that we are now seeing these same trends among older adults, who are supposed to be at the peak of their wealth accumulation and debt-free going into retirement. Lusardi and Mitchell (2013) find that even older adults on the verge of retirement (ages 56 to 61) are much more likely than their predecessors to have debt. Not only have they become increasingly more indebted, but more importantly, they have become increasingly more leveraged.

Our study shows that the prevalence as well as the absolute and relative value of debt among adults of retirement age (ages 62 to 69) also has been increasing - and even more dramatically than for those adults on the verge of retirement. Furthermore, our study suggests that older adults may be dealing with their indebtedness by delaying their retirement and Social Security benefit receipt. Those with debt are 8 percentage points more likely to work and 2 percentage points less likely to receive benefits compared with those without debt. Among the 
sources of debt, having mortgage debt consistently has a stronger impact on labor supply and Social Security receipt than having credit card or other debt. Having a mortgage increases the likelihood of working by about 7 percentage points and reduces the probability of receiving Social Security benefits by 3 percentage points. Findings based on the 2008 and 2010 waves of the HRS, when credit card debt was first collected separately from other debt, suggest that having large credit card balances is also associated with a higher propensity to work and a lower likelihood of receiving benefits. An additional $\$ 10,000$ in credit card debt increases the chances of working by 11 percentage points and decreases the chances of benefit receipt by 12 percentage points. However, because of data limitations, these results should be regarded with caution.

Delaying retirement and benefit claiming as long as possible increases financial security in retirement for everyone, but it is especially important for those with debt. So it is encouraging to find that older adults with debt are delaying both retirement and Social Security benefits. At some point, however, age and health prevent most people from working. When that time comes, how will those with debt manage their monthly mortgage and credit card payments? Possibilities include selling their homes, buying reverse mortgages, or declaring bankruptcy.

More than ever, retirement security will depend on retirees having enough income and assets to pay for basic living expenses and to service their debt. Ideally, older adults would pay off their debts well before retirement age. So it is going to be important to identify those who are financially fragile, to better understand their circumstances, and to look for ways to help repay their debt before retirement. Financial education, stricter regulations for financial and lending institutions, and controlling health care spending, a major source of debt, are all ways that policymakers might help to achieve this goal. 


\section{References}

Belkar, Rochelle, Lynne Cockerell, and Rebecca Edwards. 2007. "Labour Force Participation and Household Debt.” Research Discussion Paper No. 2007-05. Sydney: Reserve Bank of Australia.

Bottazzi, Renata. 2004. " Labour Market Participation and Mortgage-Related Borrowing Constraints.” Institute for Fiscal Studies Working Paper No. 04/09.

Bricker, Jesse, Arthur B. Kennickell, Kevin B. Moore, and John Sabelhaus. 2012. "Changes in U.S. Family Finances from 2007 to 2010: Evidence from the Survey of Consumer Finances." Federal Reserve Bulletin 98(2).

Burkhauser, Richard V., Kenneth A. Couch, and John W. Phillips. 1996. "Who Takes Early Social Security Benefits? The Economic and Health Characteristics of Early Beneficiaries." The Gerontologist 36(6): 789-99.

Butrica, Barbara. A., Karen E. Smith, and Eugene Steuerle. 2007. "Working for a Good Retirement." In D. B. Papadimitriou (Ed.), Government Spending on the Elderly (pp. 141-74). New York: Palgrave Macmillan.

Cameron, A. Colin and Pravin K. Trivedi. 2005. Microeconometrics: Methods and Applications. New York, NY: Cambridge University Press.

Caroll, Christopher D. 2001. "A Theory of the Consumption Function, with and without Liquidity Constraints." Journal of Economic Perspectives, 15(3): 23-45.

Coile, Courtney C., Peter Diamond, Jonathan Gruber, and Alain Jousten. 2002. "Delays in Claiming Social Security Benefits.” Journal of Public Economics 84(3): 357-85.

Del Boca, Daniela and Annamaria Lusardi. 2003. "Credit Market Constraints and Labor Market Decisions.” Labour Economics 10(6): 681-703.

Federal Reserve Board. 2010. "SCF Chartbook." Available at http://federalreserve.gov/econresdata/scf/files/2010_SCF_Chartbook.pdf.

Fortin, Nicole M. 1995. “Allocation Inflexibilities, Female Labor Supply and Housing Assets Accumulation: Are Women Working to Pay the Mortgage?" Journal of Labor Economics 3: 524-57.

Haaga, Owen and Richard W. Johnson. 2012. "Social Security Claiming: Trends and Business Cycle Effects." Washington, DC: Urban Institute.

Heckman, James. 1978. "Dummy Endogenous Variables in a Simultaneous Equation Systme." Econometrica 46: 931-959.

Johnson, Richard W., Karen E. Smith, and Owen Haaga. 2013. "How Did the Great Recession Affect Social Security Claiming?” Program on Retirement Policy Brief No. 37. Washington, DC: Urban Institute. 
Lusardi, Annamaria and Olivia S. Mitchell. 2013. "Debt and Debt Management among Older Adults.” Draft. Ann Arbor, MI: Michigan Retirement Research Center.

Muldoon, D. and Kopcke, R.W. 2008. "Are People Claiming Social Security Benefits Later?" Issue in Brief No. 8-7. Chestnut Hill, MA: Center for Retirement Research at Boston College.

Munnell, A.H. and Soto, M. 2005. "Why Do Women Claim Social Security Benefits So Early?" Issue in Brief No. 35. Chestnut Hill, MA: Center for Retirement Research at Boston College.

Panis, Constantijn, Michael Hurd, David Loughran, Julie Zissimopoulos, Steven Haider, and Patricia StClair. 2002. "The Effects of Changing Social Security Administration's Early Entitlement Age and the Normal Retirement Age." Santa Monica, CA: RAND.

Rossi, Mariacrisina and Serena Trucchi. 2012. "Liquidity Constraints and Labor Supply." Center for Research on Pension and Welfare Policies Working Paper No. 127/12.

Sass, Steven A., Wei Sun and Anthony Webb. 2007. "Why Do Married Men Claim Social Security Benefit So Early? Ignorance or Caddishness?” Working Paper No. 2007-17. Chestnut Hill, MA: Center for Retirement Research at Boston College.

Social Security Administration. 2012. Annual Statistical Supplement to the Social Security Bulletin, 2011. Washington, DC: Social Security Administration.

Song, Jae, and Joyce Manchester. 2007. "Have People Delayed Claiming Retirement Benefits? Responses to Changes in Social Security Rules." Social Security Bulletin 67(2): 1-23.

Sun, Wei and Anthony Webb. 2009. "How Much Do Households Really Lose by Claiming Social Security at Age 62?" Working Paper No. 2009-11. Chestnut Hill, MA: Center for Retirement Research at Boston College.

von Wachter, Till. 2009. "The Effect of Labor Market Trends on the Incentives to Incidence for Claiming Social Security Benefits Early.” Working Paper. New York, NY: Columbia University.

Wooldridge, Jeffrey M. 2002. Econometric Analysis of Cross Section and Panel Data. Cambridge, MA: MIT Press.

Zeldes, Stephen P. 1989. "Consumption and Liquidity Constraints: An Empricial Investigation", Journal of Political Economy 97(2): 305-46. 
Figure 1:

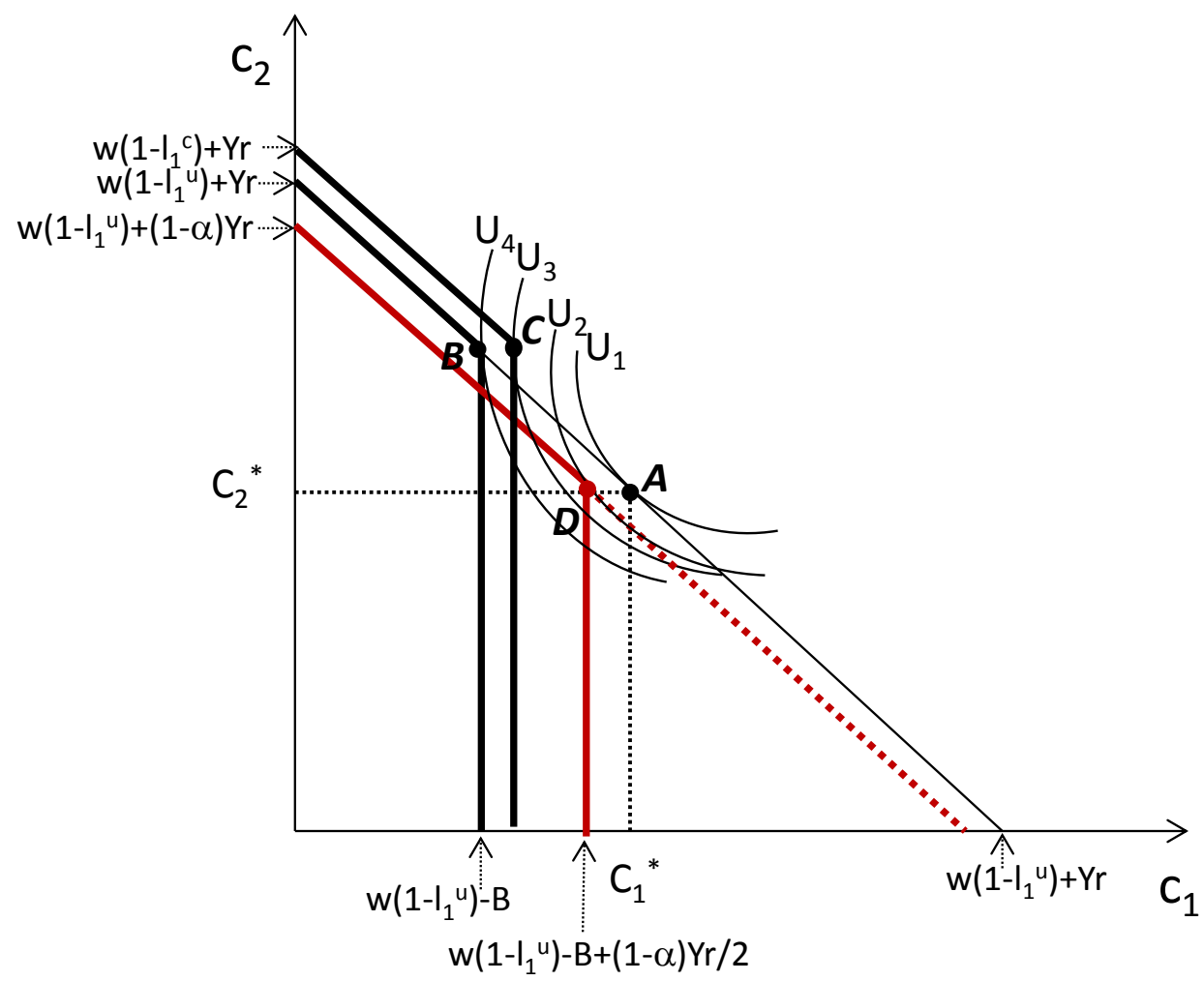

Note: For simplicity, assume further an interest rate of 0 and a discount factor of 1.

Figure 2: Share of Adults Ages 62 to 69 with Debt and the Median Value of Debt, 1998-2010

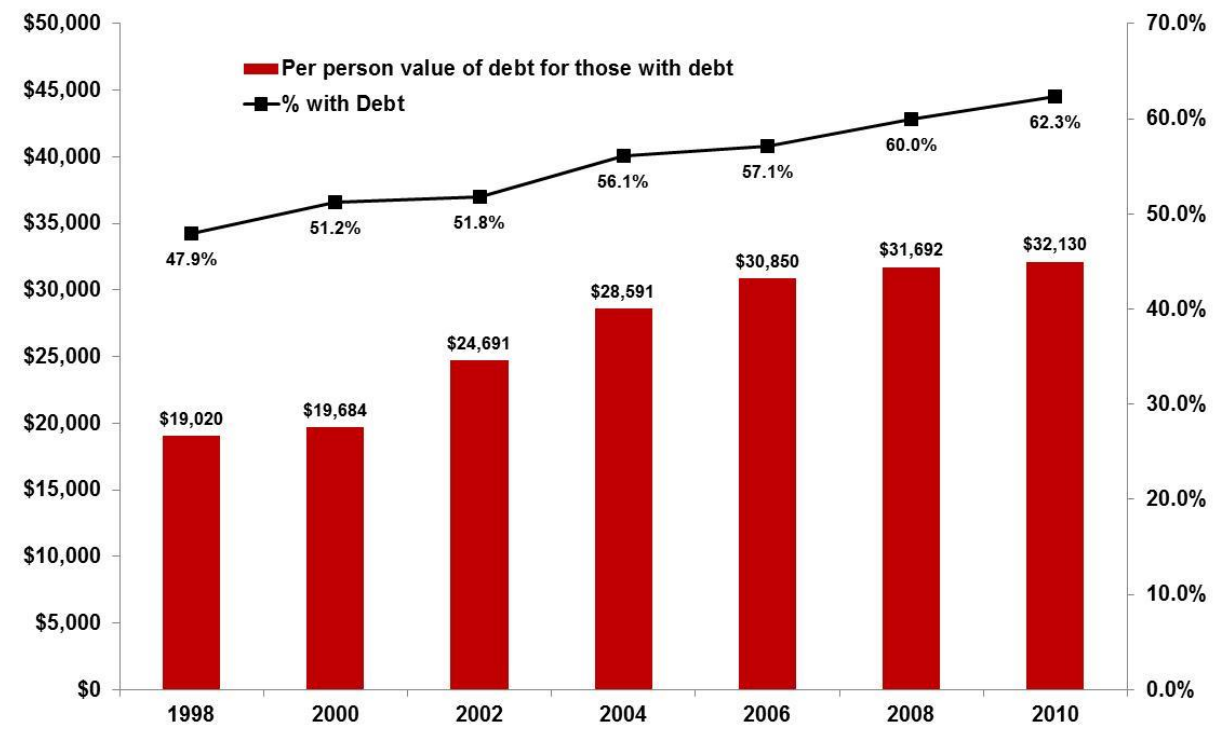

Source: Authors' calculations using 1998-2010 HRS.

Note: Dollar amounts are expressed in 2010 real dollars, adjusted by the change in the consumer price index. 
Figure 3: Share of Adults Ages 62 to 69 with Mortgages and the Median Value of the Mortgage, 1998-2010

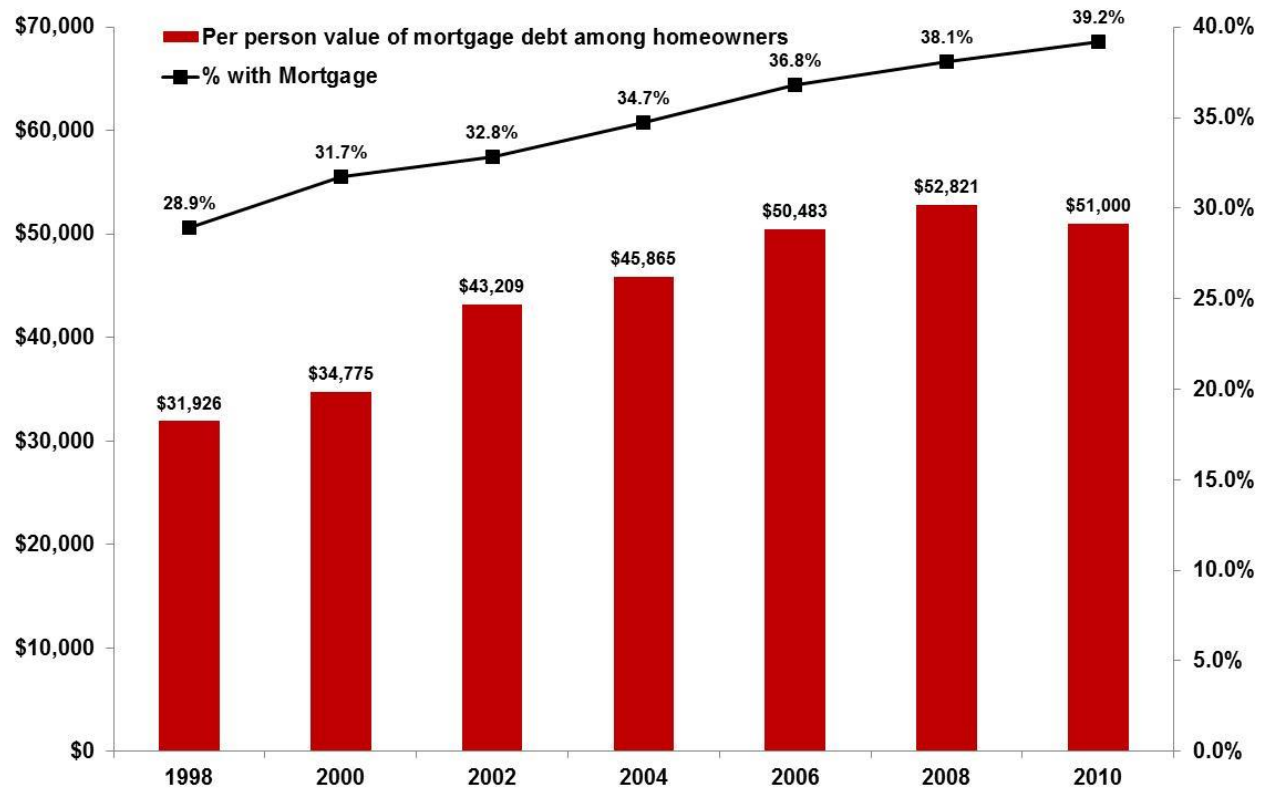

Source: Authors' calculations using 1998-2010 HRS.

Note: Dollar amounts are expressed in 2010 real dollars, adjusted by the change in the consumer price index.

Figure 4: Average Share of House Owned and the Mortgage Share of Debt among Homeowners Ages 62 to 69, 1998-2010

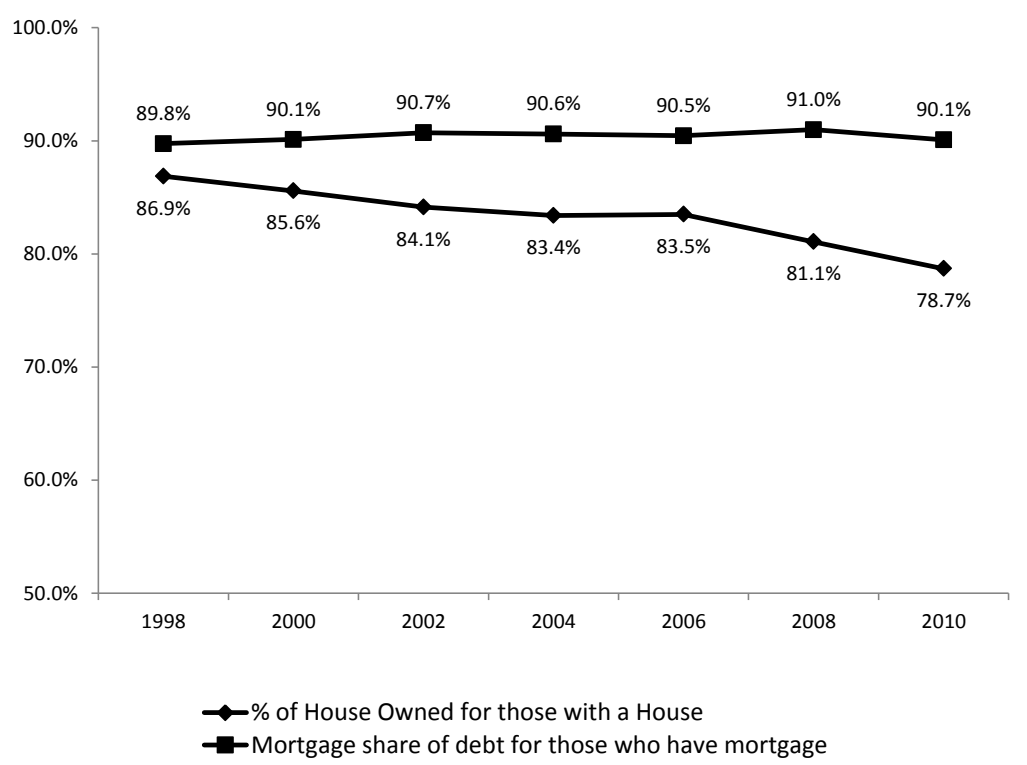

Source: Authors' calculations using 1998-2010 HRS. 
Figure 5: Share of Adults Ages 62 to 69 with Non-Mortgage Debt and Median Value of the Debt, 1998-2010

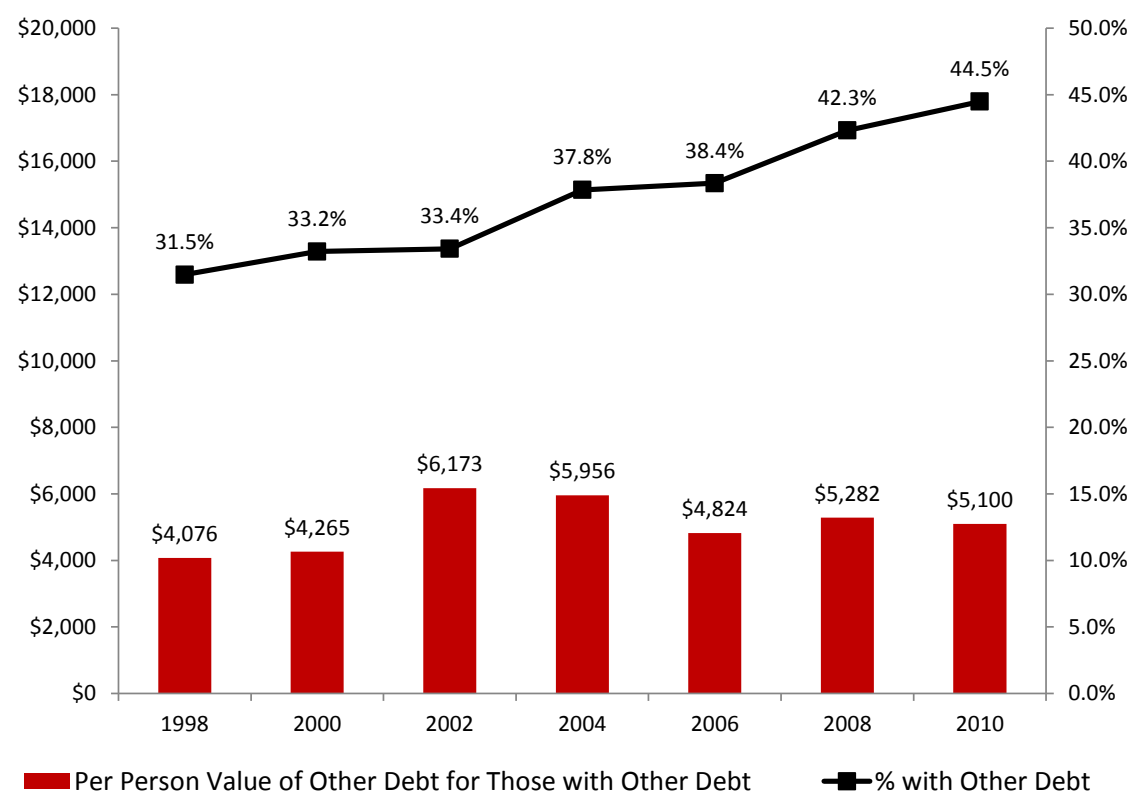

Source: Authors' calculations using 1998-2010 HRS.

Note: Dollar amounts are expressed in 2010 real dollars, adjusted by the change in the consumer price index.

Figure 6: Average Leverage Ratio among Adults Ages 62 to 69, 1998-2010

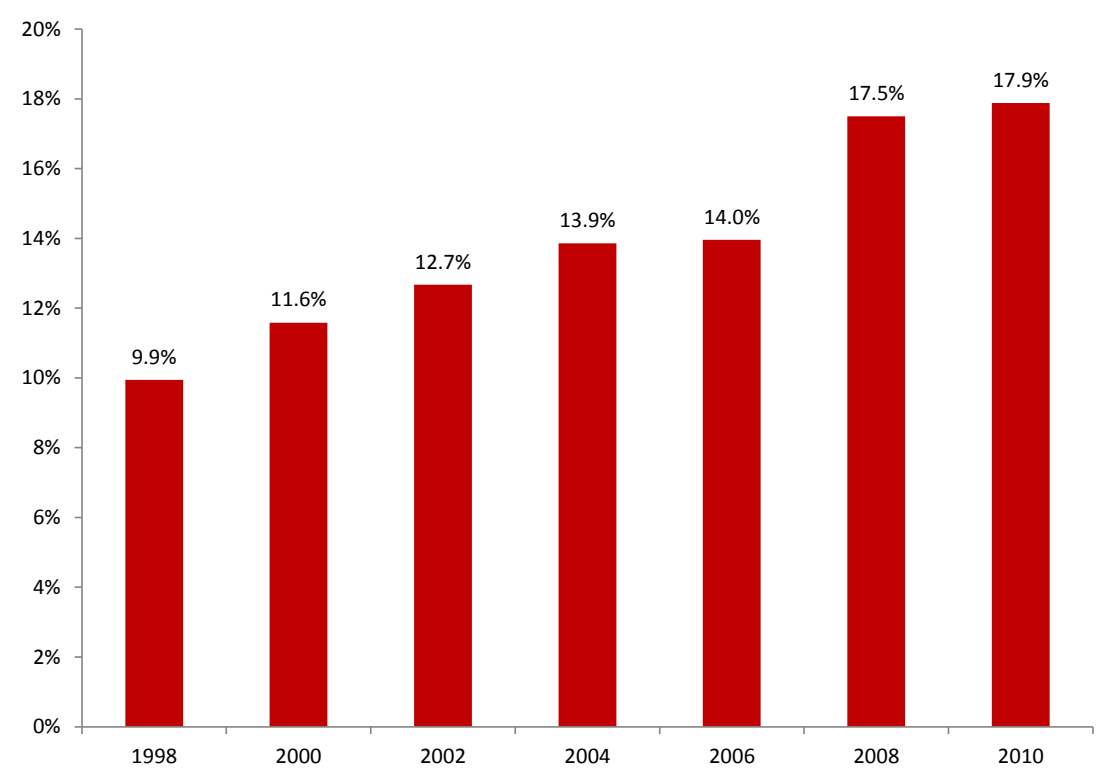

Source: Authors' calculations using 1998-2010 HRS.

Note: The top 0.5 percent of the sample with the highest leverage ratios was excluded from the calculation. 
Figure 7: Share of Adults with Debt, by Age and Year

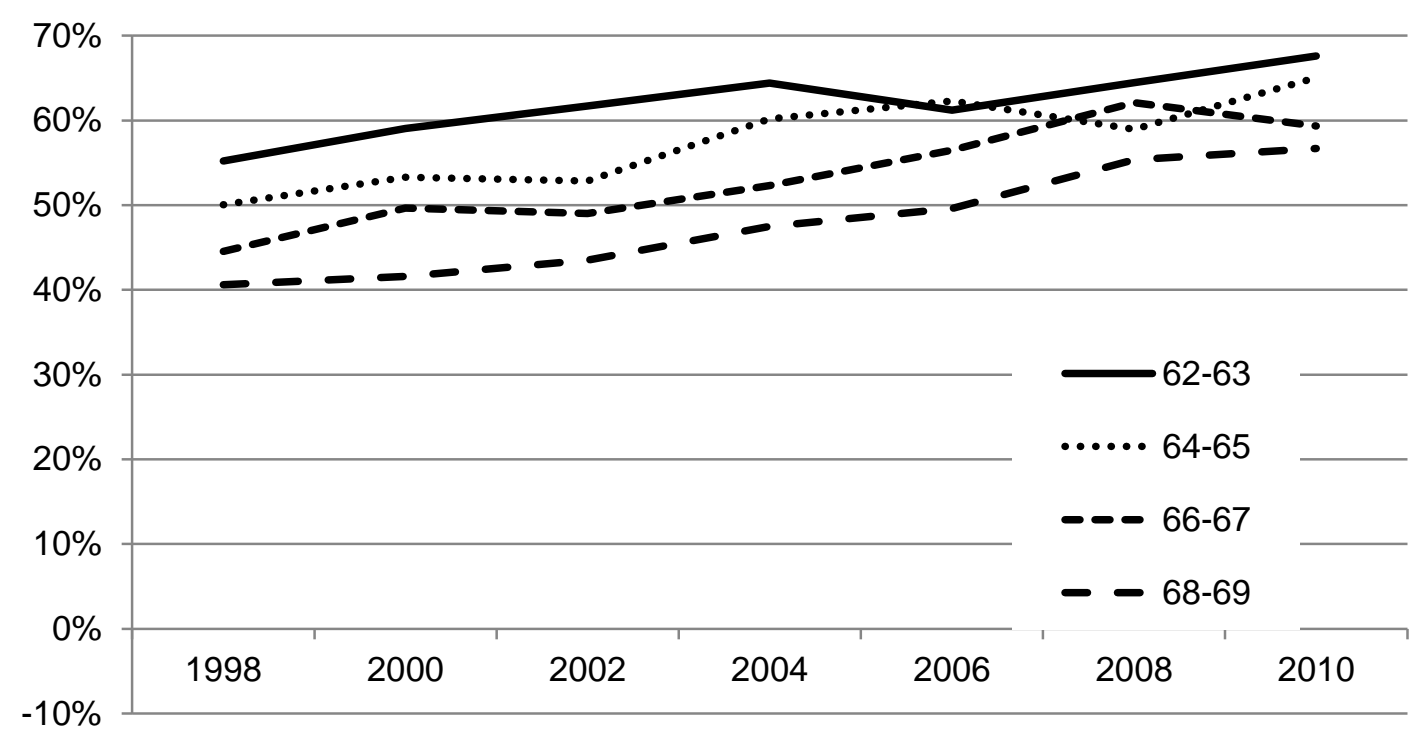

Source: Authors' calculations using 1998-2010 HRS.

Figure 8: Share of Adults with Mortgage Debt, by Age and Year

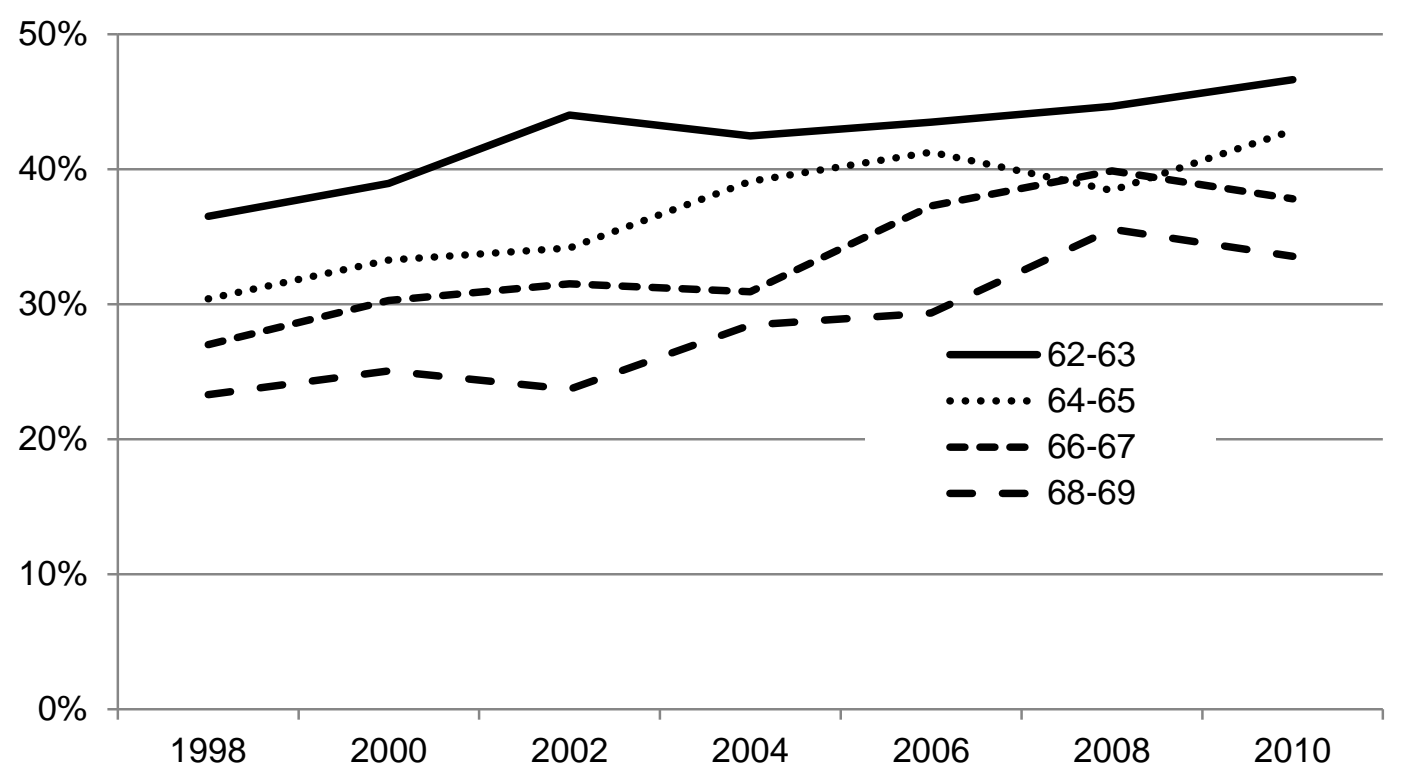

Source: Authors' calculations using 1998-2010 HRS. 
Figure 9: Share of Adults Ages 62 to 69 with Debt, by Income and Year

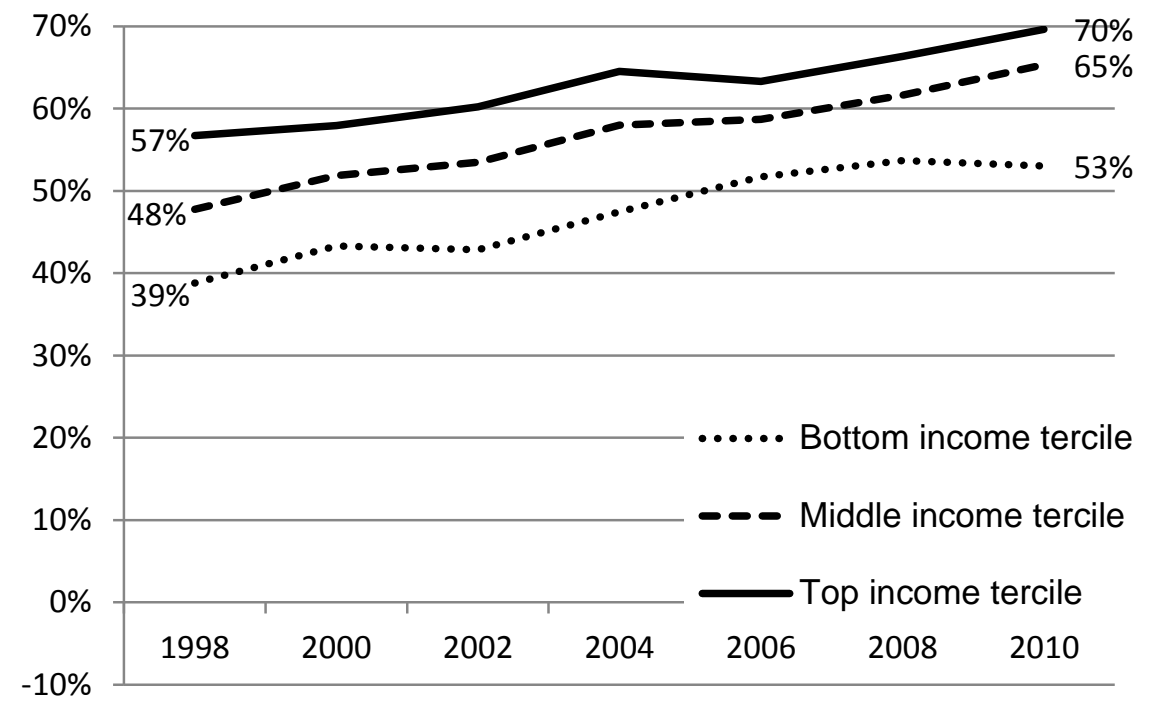

Note: Income terciles are based on per person total income in each year.

Source: Authors' calculations using 1998-2010 HRS.

Figure 10: Share of Adults Ages 62 to 69 with Mortgage Debt, by Income and Year

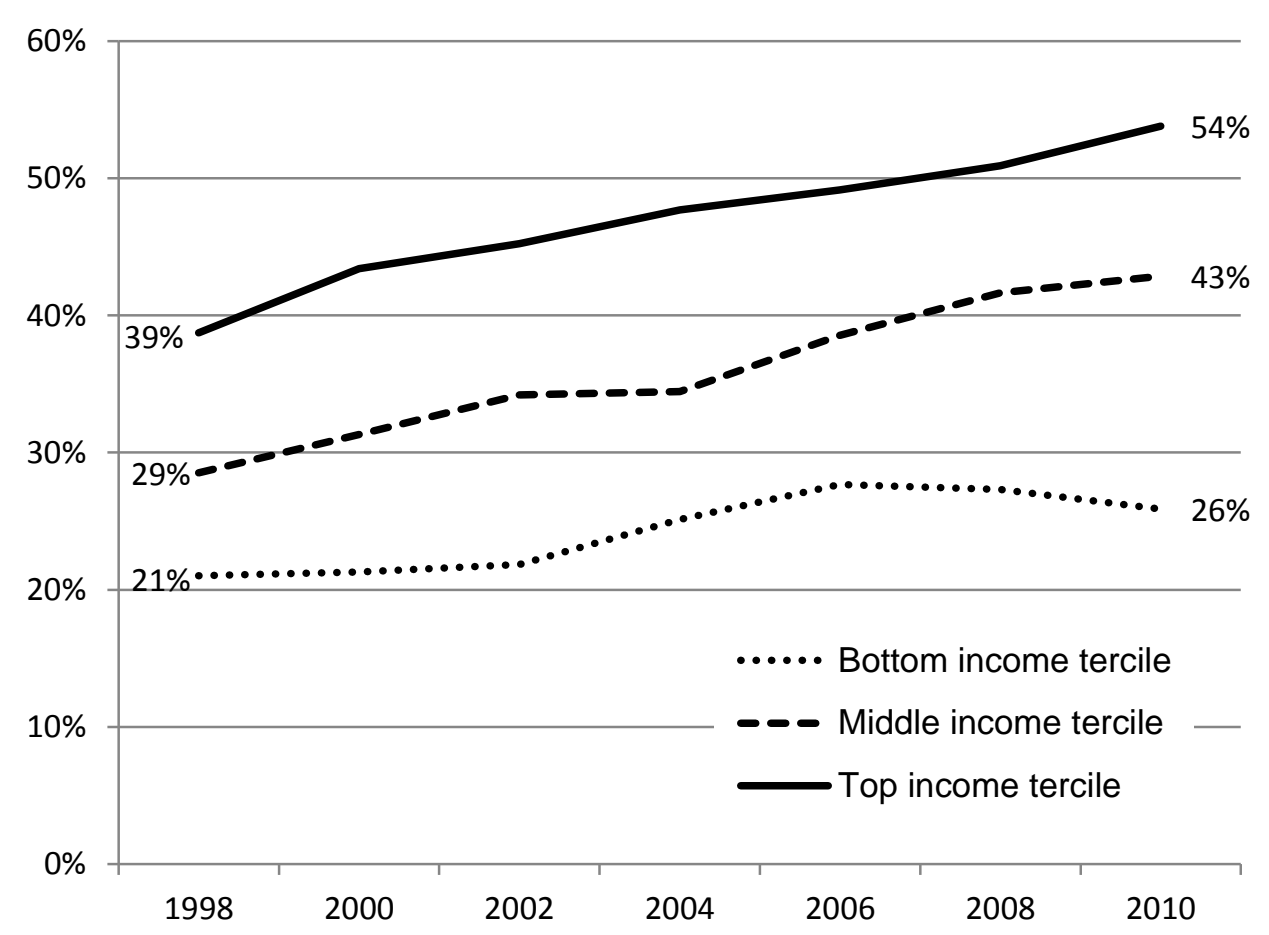

Note: Income terciles are based on per person total income in each year.

Source: Authors' calculations using 1998-2010 HRS. 
Figure 11: Probability of Not Having Fully Retired among Adults Ages 62 to 69, by Debt

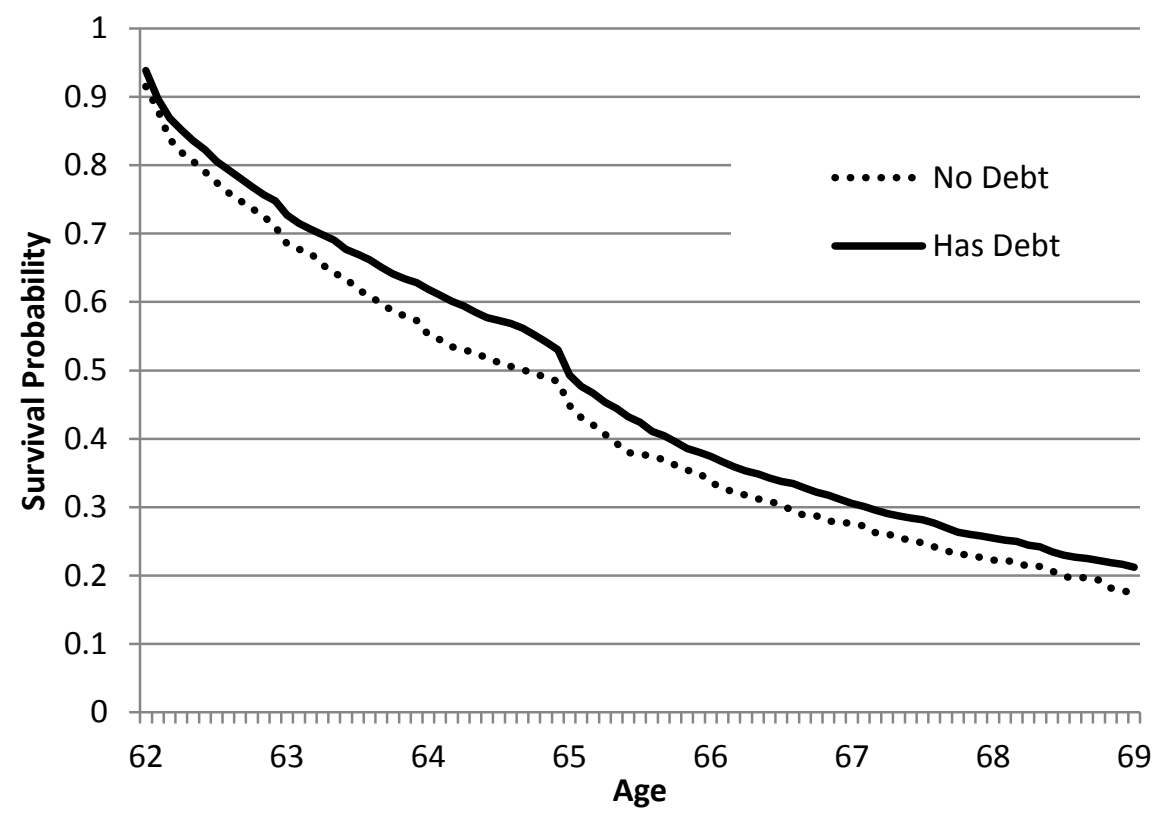

Note: Having debt is defined at the beginning of the spell.

Source: Authors' calculations, using 1992-2010 HRS and Kaplan-Meier estimation method.

Figure 12: Probability of Not Having Fully Retired among Adults Ages 62 to 69, by Mortgage Debt

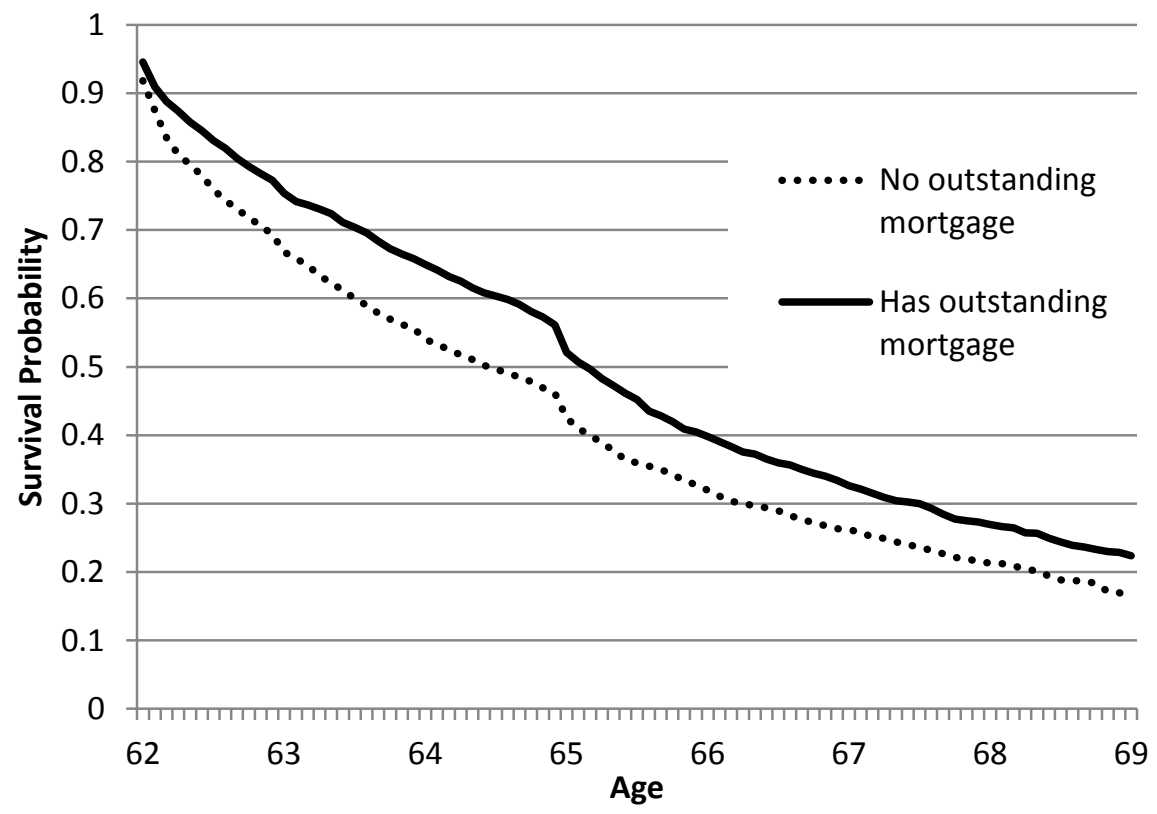

Note: Having mortgage debt is defined at the beginning of the spell.

Source: Authors' calculations, using 1992-2010 HRS and Kaplan-Meier estimation method. 
Figure 13: Probability of Not Having Claimed Social Security Benefits among Adults Ages 62 to 69, by Debt

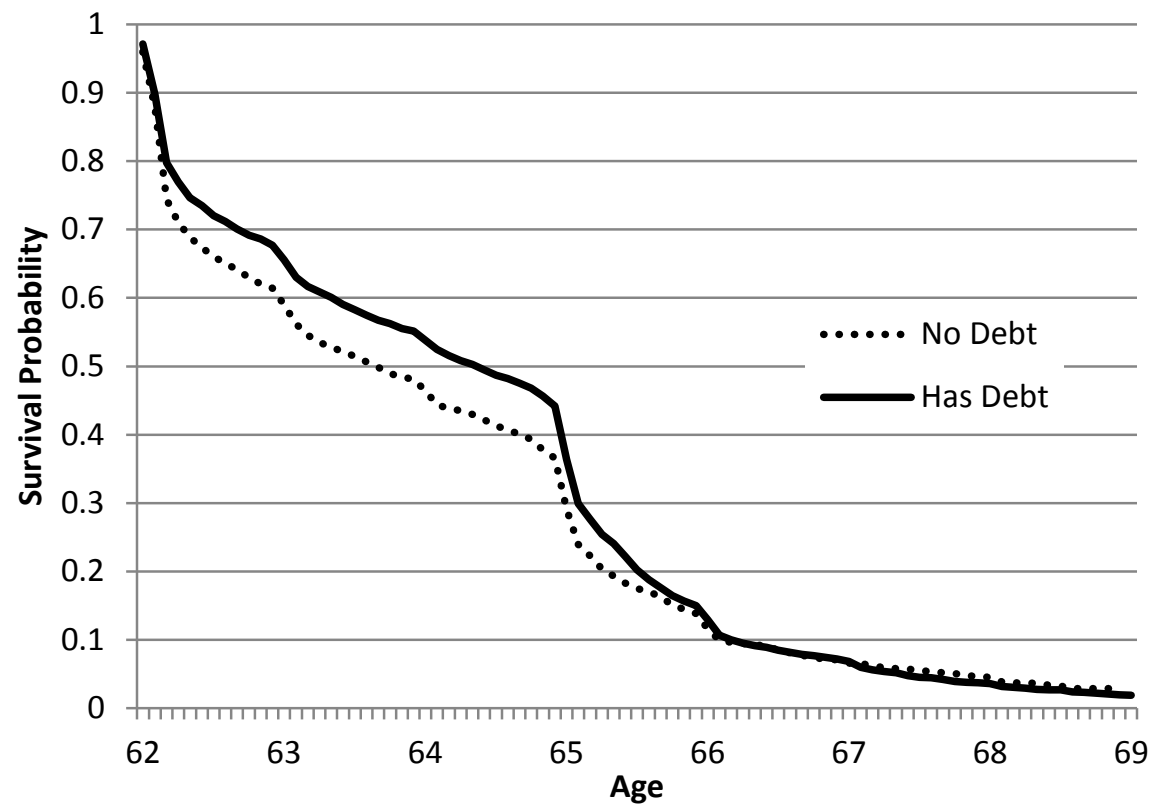

Note: Having debt is defined at the beginning of the spell.

Source: Authors' calculations, using 1992-2010 HRS and Kaplan-Meier estimation method.

Figure 14: Probability of Not Having Claimed Social Security Benefits among Adults Ages 62 to 69, by Mortgage Debt

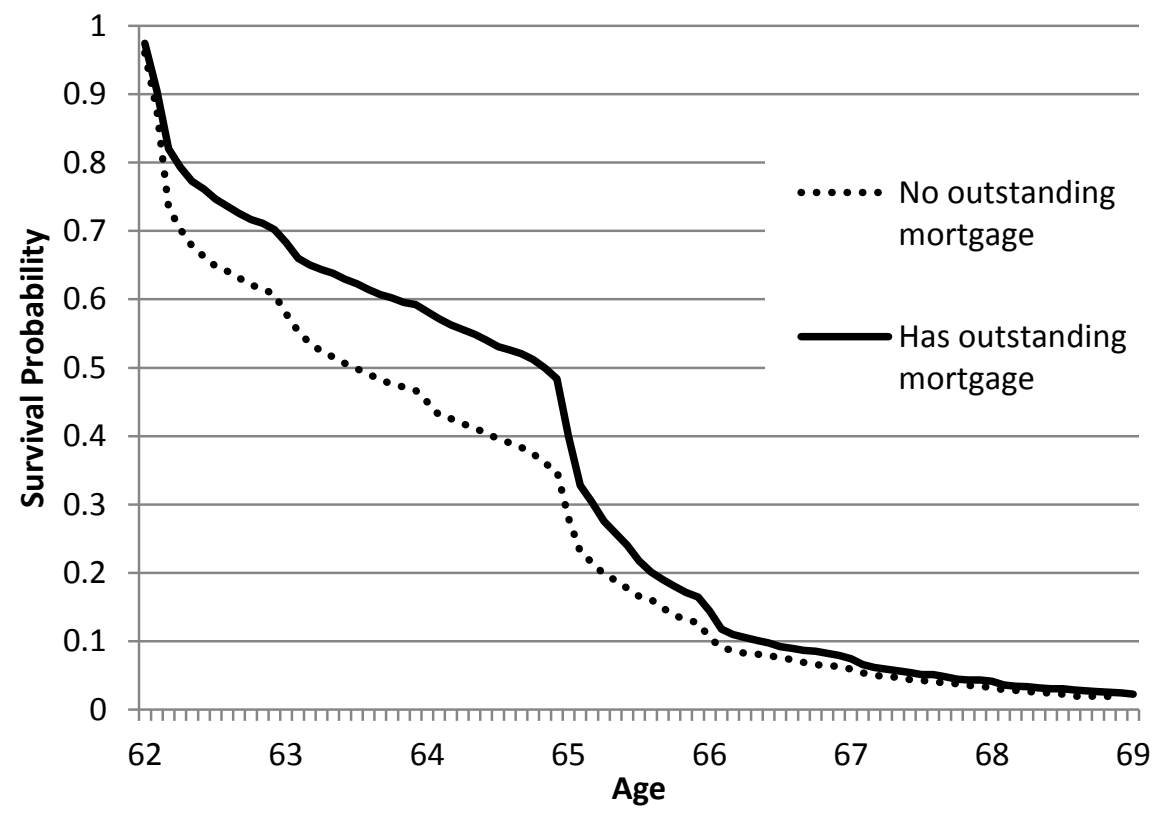

Note: Having mortgage debt is defined at the beginning of the spell.

Source: Authors' calculations, using 1992-2010 HRS and Kaplan-Meier estimation method. 
Table 1: Share of Adults Ages 62 to 69 Working or Receiving Social Security Benefits, by Debt

\begin{tabular}{|c|c|c|c|c|c|c|c|c|c|}
\hline & No Debt & Debt & & $\begin{array}{c}\text { No } \\
\text { Mortgage }\end{array}$ & Mortgage & & $\begin{array}{l}\text { No Credit } \\
\text { Card Debt }\end{array}$ & $\begin{array}{c}\text { Credit } \\
\text { Card Debt }\end{array}$ & \\
\hline \multicolumn{10}{|c|}{ \% Working } \\
\hline All & $33.3 \%$ & $46.3 \%$ & $* * *$ & $35.6 \%$ & $49.6 \%$ & $* * *$ & $40.1 \%$ & $47.0 \%$ & $* * *$ \\
\hline \multicolumn{10}{|l|}{ Age } \\
\hline $62-63$ & $45.4 \%$ & $57.9 \%$ & $* * *$ & $48.0 \%$ & $60.3 \%$ & $* * *$ & $52.7 \%$ & $59.3 \%$ & $* *$ \\
\hline $64-65$ & $37.5 \%$ & $48.5 \%$ & $* * *$ & $39.6 \%$ & $51.1 \%$ & $* * *$ & $44.4 \%$ & $49.7 \%$ & $*$ \\
\hline $66-67$ & $29.5 \%$ & $40.8 \%$ & $* * *$ & $31.3 \%$ & $44.1 \%$ & $* * *$ & $37.3 \%$ & $43.4 \%$ & $* *$ \\
\hline $68-69$ & $24.9 \%$ & $36.0 \%$ & $* * *$ & $26.6 \%$ & $39.4 \%$ & $* * *$ & $31.6 \%$ & $38.8 \%$ & $* * *$ \\
\hline \multicolumn{10}{|c|}{ \% Receiving Social Security benefits } \\
\hline All & $77.9 \%$ & $70.8 \%$ & $* * *$ & $77.3 \%$ & $67.8 \%$ & $* * *$ & $75.2 \%$ & $74.0 \%$ & \\
\hline \multicolumn{10}{|l|}{ Age } \\
\hline $62-63$ & $43.9 \%$ & $37.5 \%$ & $* * *$ & $43.4 \%$ & $35.0 \%$ & $* * *$ & $35.3 \%$ & $36.2 \%$ & \\
\hline $64-65$ & $72.2 \%$ & $66.0 \%$ & $* * *$ & $72.2 \%$ & $62.5 \%$ & $* * *$ & $63.0 \%$ & $61.9 \%$ & \\
\hline $66-67$ & $91.3 \%$ & $91.0 \%$ & & $91.7 \%$ & $90.0 \%$ & $* *$ & $90.6 \%$ & $91.5 \%$ & \\
\hline $68-69$ & $94.4 \%$ & $94.2 \%$ & & $94.6 \%$ & $93.5 \%$ & $*$ & $95.4 \%$ & $96.4 \%$ & \\
\hline
\end{tabular}

Source: Authors' calculations using the 1998-2010 HRS. Note: Credit card debt information is available only in the 2008 and 2010 waves of the HRS. Sample excludes disabled individuals. Significance levels reported for t-tests of difference in means: $* * * \mathrm{p}<0.01 ; * * \mathrm{p}<0.05 ; * \mathrm{p}<0.1$ 
Table 2: Marginal Effects from Bivariate Probit Results of Labor Force Participation and Social Security Receipt among Adults Ages 62 to 69

\begin{tabular}{|c|c|c|c|c|c|c|}
\hline & \multicolumn{6}{|c|}{$\operatorname{Pr}($ work $=1)$} \\
\hline Variable & (1) & (2) & (3) & (4) & (5) & (6) \\
\hline Had debt & $\begin{array}{l}0.0811 * * \\
(0.0083)\end{array}$ & & & & & \\
\hline Has non-mortgage debt & & $\begin{array}{l}0.0568 * * * \\
(0.0080)\end{array}$ & $\begin{array}{l}0.0006 \\
(0.0192)\end{array}$ & & & \\
\hline Has outstanding mortgage & & $\begin{array}{l}0.0707 * * * \\
(0.0092)\end{array}$ & $\begin{array}{l}0.0741 * * * \\
(0.0168)\end{array}$ & & & \\
\hline Has credit card debt & & & $\begin{array}{l}0.0432 * * \\
(0.0219)\end{array}$ & & & \\
\hline $\begin{array}{l}\text { Per person value of total } \\
\text { debt }\end{array}$ & & \multicolumn{5}{|c|}{$\begin{array}{l}0.0066 * * * \\
(0.0009)\end{array}$} \\
\hline $\begin{array}{l}\text { Per person value of non- } \\
\text { mortgage debt }\end{array}$ & & & & & $\begin{array}{l}0.0071 * * * \\
(0.0018)\end{array}$ & $\begin{array}{l}0.0004 \\
(0.0026)\end{array}$ \\
\hline $\begin{array}{l}\text { Per person value of } \\
\text { outstanding mortgage }\end{array}$ & & & & & $\begin{array}{l}0.0064 * * * \\
(0.0010)\end{array}$ & $\begin{array}{l}0.0049 * * * \\
(0.0016)\end{array}$ \\
\hline $\begin{array}{l}\text { Per person value of credit } \\
\text { card debt }\end{array}$ & & & & & & $\begin{array}{l}0.1063 * * \\
(.0525)\end{array}$ \\
\hline & \multicolumn{6}{|c|}{$\operatorname{Pr}($ receive $\mathrm{SS}=1$ ) } \\
\hline Variable & $(1)$ & $(2)$ & (3) & (4) & & (6) \\
\hline Had debt & $\begin{array}{l}- \\
0.0175 * * \\
(0.0071)\end{array}$ & & & & & \\
\hline Has non-mortgage debt & & $\begin{array}{l}0.0026 \\
(0.0068)\end{array}$ & $\begin{array}{l}-0.0018 \\
(0.0160)\end{array}$ & & & \\
\hline Has outstanding & & - & & & & \\
\hline mortgage & & $\begin{array}{l}0.0293 * * * \\
(0.0078)\end{array}$ & $\begin{array}{l}-0.0287 * * \\
(0.0137)\end{array}$ & & & \\
\hline Has credit card debt & & & $\begin{array}{l}0.0179 \\
(0.0173)\end{array}$ & & & \\
\hline $\begin{array}{l}\text { Per person value of total } \\
\text { debt }\end{array}$ & & & & $\begin{array}{l}-0.0026 * * * \\
(0.0006)\end{array}$ & & \\
\hline $\begin{array}{l}\text { Per person value of non- } \\
\text { mortgage debt }\end{array}$ & & & & & $\begin{array}{l}-0.0011 \\
(0.0013)\end{array}$ & $\begin{array}{l}-0.0021 \\
(0.0019)\end{array}$ \\
\hline $\begin{array}{l}\text { Per person value of } \\
\text { outstanding mortgage }\end{array}$ & & & & & $\begin{array}{l}- \\
0.0034 * * * \\
(0.0008)\end{array}$ & $\begin{array}{l}-0.0023 * * \\
(0.0011)\end{array}$ \\
\hline
\end{tabular}


Per person value of credit card debt

\begin{tabular}{lllllll}
\hline Observations & 27585 & 27585 & 5331 & 27585 & 27585 & 5331 \\
\hline
\end{tabular}

Source: Authors' calculations, using 1992-2010 HRS.

Notes: Standard errors in brackets; Significance *** $\mathrm{p}<0.01 ; * * \mathrm{p}<0.05 ; * \mathrm{p}<0.1$.

Table 3: Marginal Effects from Bivariate Probit Results of Labor Force Participation and Social Security Receipt among Homeowners Ages 62 to 69

\begin{tabular}{lllll}
\hline & $\operatorname{Pr}($ Work=1) \\
\hline Variable & $(1)$ & $(2)$ & $(3)$ & $(4)$ \\
\hline
\end{tabular}

Has non-mortgage debt

Has outstanding mortgage

Per person value of non-

mortgage debt

Per person value of outstanding mortgage

Ratio of non-mortgage

debt/Assets

Ratio of Mortgage/Assets

Ratio of non-mortgage

debt/Other income

Ratio of Mortgage/Other income
$0.0521 * * *$

(0.0084)

$0.0778 * * *$

(0.0095)

$0.0073 * *$

$*$

(0.0019)

$0.0067 * *$

*

(0.0011)
$0.0006^{* *}$

(0.0002)

$0.0010 * * *$

(0.0002)

\begin{tabular}{lllll}
\hline & \multicolumn{5}{c}{$\operatorname{Pr}($ receive $\mathrm{SS}=1)$} \\
\hline Variable & $(1)$ & $(2)$ & $(3)$ & $(4)$ \\
\hline
\end{tabular}

Has non-mortgage debt

0.0003

$(0.0072)$

Has outstanding mortgage

$-0.0390 * * *$

Per person value of non-mortgage

debt

(0.0080)

0.0005

(0.0004)

$0.0004 * *$

(0.0002)

\section{(2)}

$-0.0008$

(0.0013)

Per person value of outstanding mortgage

$-0.0039 * * *$ 
Ratio of non-mortgage debt/Assets

Ratio of Mortgage/Assets

Ratio of non-mortgage debt/Other

income

Ratio of Mortgage/Other income
(0.0008)

0.0001

$(0.0001)$

$-0.0004 * * *$

$(0.0001)$

$-0.0005^{*}$

$(0.0003)$

$0.0004 * * *$

$(0.0001)$

Observations

24624

24624

24624

24624

Source: Authors' calculations, using 1992-2010 HRS.

Notes: Standard errors in brackets; Significance $* * * \mathrm{p}<0.01 ; * * \mathrm{p}<0.05 ; * \mathrm{p}<0.1$. 
Table 4: Hazard Model of Full Retirement and Social Security Benefit Claiming among Adults Ages 62 to 69

Exit from Labor Force (i.e. full retirement)

Variable

Odds Ratios

(1)

(2) (3)

Has debt

$0.7756 * * *$

(0.0356)

Has non-mortgage debt

Has outstanding mortgage

Per person value of total debt

Per person value of non-mortgage

debt

Per person value of outstanding mortgage
$0.7934 * * *$

(0.0367)

$0.8461 * * *$

$(0.0398)$

(0.0052)

\begin{tabular}{|c|c|c|c|c|}
\hline \multirow{2}{*}{\multicolumn{5}{|c|}{ Exit to Social Security Receipt }} \\
\hline & & & & \\
\hline \multirow[t]{2}{*}{ Variable } & \multicolumn{4}{|c|}{ Odds Ratios } \\
\hline & (1) & $(2)$ & (3) & (4) \\
\hline Has debt & $\begin{array}{l}0.8600 * * * \\
(0.0349)\end{array}$ & & & \\
\hline Has non-mortgage debt & & $\begin{array}{l}0.9334^{*} \\
(0.0371)\end{array}$ & & \\
\hline Has outstanding mortgage & & $\begin{array}{l}0.8499 * * * \\
(0.0349)\end{array}$ & & \\
\hline Per person value of total debt & & & $\begin{array}{l}0.9832 * * * \\
(0.0039)\end{array}$ & \\
\hline $\begin{array}{l}\text { Per person value of non-mortgage } \\
\text { debt }\end{array}$ & & & & $\begin{array}{l}0.9937 \\
(0.0091)\end{array}$ \\
\hline $\begin{array}{l}\text { Per person value of outstanding } \\
\text { mortgage }\end{array}$ & & & & $\begin{array}{l}0.9793 * * * \\
(0.0040)\end{array}$ \\
\hline
\end{tabular}

Source: Authors' calculations, using 1992-2010 HRS.

Notes: Results show log-odds ratios. Standard errors are shown in brackets; Significance $* * * \mathrm{p}<0.01 ; * * \mathrm{p}<0.05 ; *$ $\mathrm{p}<0.1$. 
Table 5: Labor Force Participation with Endogenous Mortgage Constraint among Homeowners Ages 62 to 69

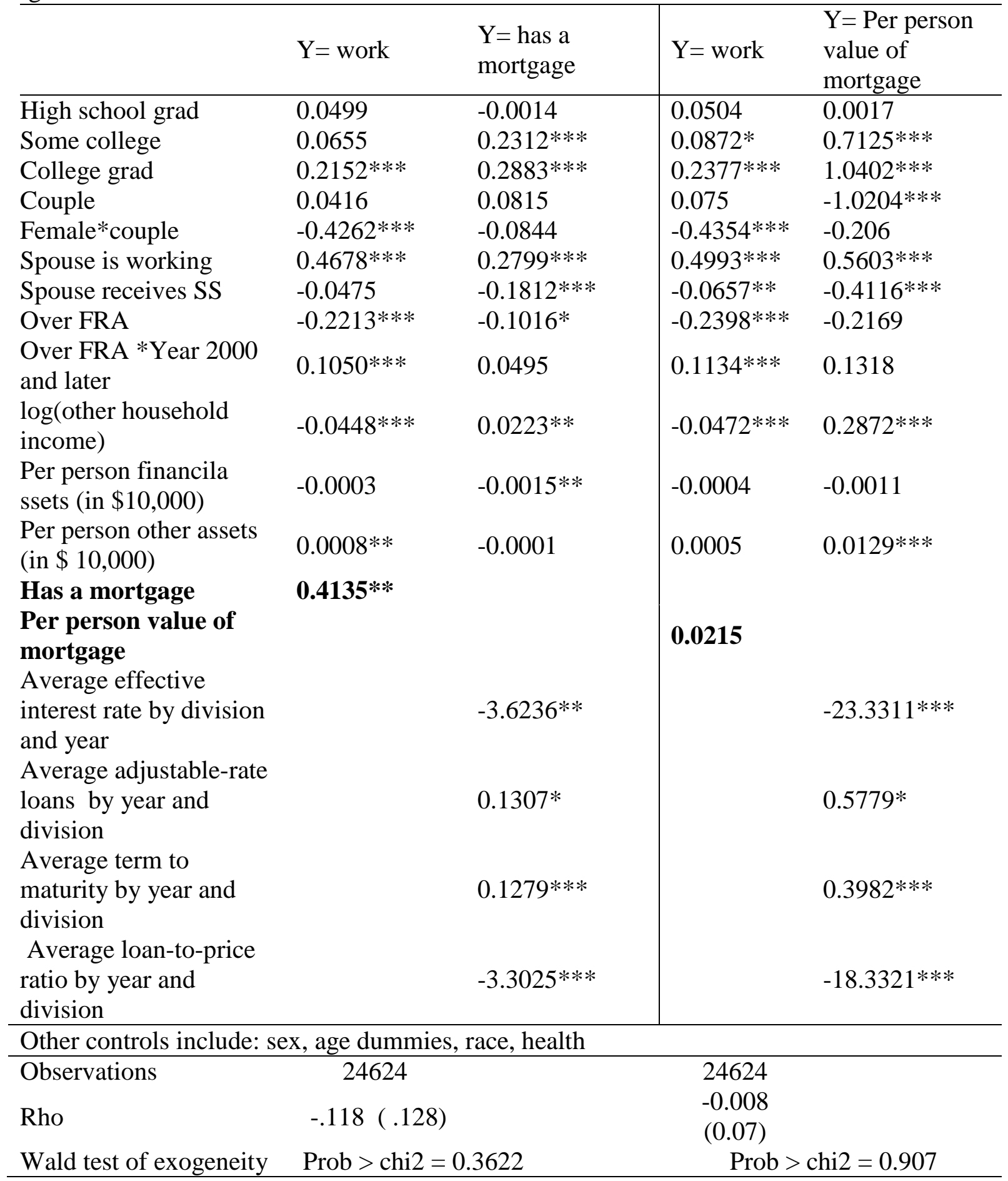

Source: Authors' calculations, using 1992-2010 HRS.

Notes: Standard errors in brackets; Significance $* * * p<0.01 ; * * \mathrm{p}<0.05 ; * \mathrm{p}<0.1$. 
Table 6: Social Security Receipt with Endogenous Mortgage Constraint among Homeowners Ages 62 to 69

\begin{tabular}{|c|c|c|c|c|}
\hline & \multicolumn{2}{|c|}{ (1) } & \multicolumn{2}{|c|}{ (2) } \\
\hline & $\begin{array}{l}\text { Y=receive } \\
\text { SS }\end{array}$ & $\begin{array}{c}\mathrm{Y}=\text { has a } \\
\text { mortgage }\end{array}$ & $\begin{array}{c}\mathrm{Y}= \\
\text { receive SS }\end{array}$ & $\begin{array}{c}\mathrm{Y}=\text { Per } \\
\text { person } \\
\text { value of } \\
\text { mortgage }\end{array}$ \\
\hline High school grad & $\overline{-}-1591 * * *$ & -0.0004 & $-\overline{1}-1577 * * *$ & 0.0036 \\
\hline Some college & $\overline{0}-2244 * * *$ & $0.2332 * * *$ & $\overline{0}-2227 * * *$ & $0.7151^{* * *}$ \\
\hline College grad & $-\overline{0.6090 * * *}$ & $0.2904 * * *$ & $-\overline{0} 6055^{* * *}$ & $1.0445^{* * *}$ \\
\hline Couple & $-0.1312 * *$ & 0.0798 & $-0.1463 * *$ & $-1.0191 * * *$ \\
\hline Female*couple & $\overline{0}-3621 * * *$ & -0.0819 & $\overline{0} 3614 * * *$ & -0.2048 \\
\hline Spouse is working & $\overline{0}-1533 * * *$ & $0.2793 * * *$ & $\overline{0.1575 * * *}$ & $0.5593 * * *$ \\
\hline Spouse receives SS & $0.5980^{* * *}$ & $0.1810^{* * *}$ & $0.5990 * * *$ & $-0.4126^{* * *}$ \\
\hline Over FRA & $0.1946 * * *$ & $-0.1078 * *$ & $0.1902 * * *$ & -0.2246 \\
\hline Over FRA *Year 2000 and later & $0.1911 * * *$ & 0.0519 & $0.1955^{* * *}$ & 0.1321 \\
\hline $\log$ (other household income) & 0.0085 & $0.0223 * *$ & 0.0112 & $0.2864 * * *$ \\
\hline Per person financila ssets (in $\$ 10,000$ ) & 0.0001 & $-0.0014 * *$ & 0.0001 & -0.0012 \\
\hline Per person other assets (in $\$ 10,000$ ) & $-0.0006^{* *}$ & -0.0001 & -0.0005 & $0.0129 * * *$ \\
\hline $\begin{array}{l}\text { Has a mortgage } \\
\text { Per person value of mortgage }\end{array}$ & -0.0887 & & -0.0102 & \\
\hline $\begin{array}{l}\text { Average effective interest rate by } \\
\text { division and year }\end{array}$ & & $-3.2972 * *$ & & $-\overline{23.2830^{* * *}}$ \\
\hline $\begin{array}{l}\text { Average adjustable-rate loans by year } \\
\text { and division }\end{array}$ & & $0.1411 *$ & & $0.5794 *$ \\
\hline $\begin{array}{l}\text { Average term to maturity by year and } \\
\text { division }\end{array}$ & & $0.1272 * * *$ & & $0.3975 * * *$ \\
\hline Average loan-to-price ratio by year & & - & & - \\
\hline and division & & $3.3750 * * *$ & & $18.3441 * *$ \\
\hline \multicolumn{5}{|c|}{ Other controls include: sex, age dummies, race, health } \\
\hline Observations & 24624 & & 24624 & \\
\hline Rho & $\begin{array}{l}-.021 \\
(.099)\end{array}$ & & $\begin{array}{l}-.011 \\
(.067)\end{array}$ & \\
\hline Wald test of exogeneity & Prob $>$ chi 2 & $=0.8351$ & Prob $>\mathrm{ch}$ & $2=0.8709$ \\
\hline
\end{tabular}

Source: Authors' calculations, using 1992-2010 HRS.

Notes: Standard errors in brackets; Significance *** $\mathrm{p}<0.01 ; * * \mathrm{p}<0.05 ; * \mathrm{p}<0.1$. 
Table 7: Marginal Effects from Random Effects Probit Results of Labor Force Participation and Social Security Receipt among Adults Ages 62 to 69

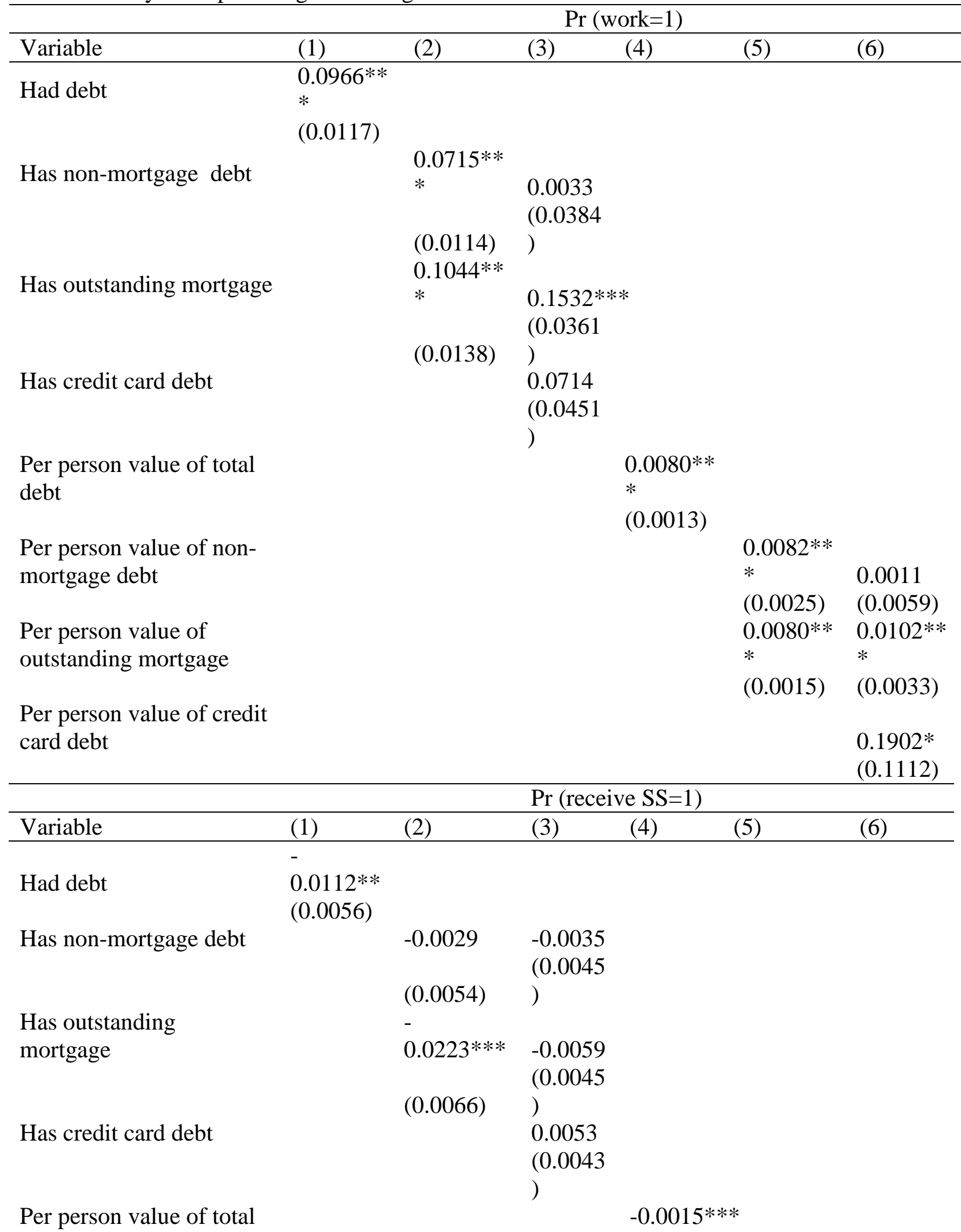


debt

(0.0005

)

Per person value of non-

mortgage debt

$-0.0002 \quad-0.0007$

(0.0009) (0.0006)

Per person value of

outstanding mortgage

$0.0023 * * * \quad-0.0005$

(0.0007) (0.0004)

Per person value of credit

$0.0333 *$

card debt

(0.0185)

Observations

27600

27600

5332

$27600 \quad 27600$

5332

Source: Authors' calculations, using 1992-2010 HRS.

Notes: Standard errors in brackets; Significance $* * * \mathrm{p}<0.01 ; * * \mathrm{p}<0.05 ; * \mathrm{p}<0.1$. 
Table 8: Marginal Effects from Bivariate Probit Results of Labor Force Participation and Social Security Receipt among Adults Ages 62 to 69, by Gender

\begin{tabular}{|c|c|c|c|c|c|c|c|c|}
\hline & \multicolumn{8}{|c|}{$\operatorname{Pr}($ work $=1)$} \\
\hline & \multicolumn{4}{|c|}{ Men } & \multicolumn{4}{|c|}{ Women } \\
\hline Variable & (1) & (2) & (3) & (4) & (1) & (2) & (3) & (4) \\
\hline Has debt & $\begin{array}{l}0.0694 * * * \\
(0.0125)\end{array}$ & & & & $\begin{array}{l}0.0838 * * * \\
(0.0108)\end{array}$ & & & \\
\hline Has non-mortgage debt & & $\begin{array}{l}0.0502 * * * \\
(0.0115)\end{array}$ & & & & $\begin{array}{l}0.0573 * * * \\
(0.0106)\end{array}$ & & \\
\hline Has outstanding mortgage & & $\begin{array}{l}0.0560 * * * \\
(0.0133)\end{array}$ & & & & $\begin{array}{l}0.0803 * * * \\
(0.0123)\end{array}$ & & \\
\hline $\begin{array}{l}\text { Per person value of total } \\
\text { debt }\end{array}$ & \multicolumn{4}{|c|}{$\begin{array}{l}0.0057 * * * \\
(0.0013)\end{array}$} & & \multicolumn{3}{|c|}{$\begin{array}{l}0.0067 * * * \\
(0.0012)\end{array}$} \\
\hline $\begin{array}{l}\text { Per person value of non- } \\
\text { mortgage debt }\end{array}$ & & & & $\begin{array}{l}0.0065 * * * \\
(0.0023)\end{array}$ & & & & $\begin{array}{l}0.0071 * * * \\
(0.0024)\end{array}$ \\
\hline $\begin{array}{l}\text { Per person value of } \\
\text { outstanding mortgage }\end{array}$ & & & & $\begin{array}{l}0.0055 * * * \\
(0.0016)\end{array}$ & & & & $\begin{array}{l}0.0065^{* * *} \\
(0.0013)\end{array}$ \\
\hline & \multicolumn{8}{|c|}{$\operatorname{Pr}$ (receive $\mathrm{SS}=1$ ) } \\
\hline & \multicolumn{4}{|c|}{ Men } & \multicolumn{4}{|c|}{ Women } \\
\hline Variable & (1) & (2) & (3) & (4) & (1) & (2) & (3) & (4) \\
\hline Has debt & $\begin{array}{l}0.0287 * * * \\
(0.0110)\end{array}$ & & & & $\begin{array}{l}-0.0080 \\
(0.0092)\end{array}$ & & & \\
\hline Has non-mortgage debt & & $\begin{array}{l}-0.0074 \\
(0.0106) \\
-\end{array}$ & & & & $\begin{array}{l}0.0104 \\
(0.0089)\end{array}$ & & \\
\hline Has outstanding mortgage & & $\begin{array}{l}- \\
0.0385 * * * \\
(0.0118)\end{array}$ & & & & $\begin{array}{l}-0.0199 * \\
(0.0104)\end{array}$ & & \\
\hline $\begin{array}{l}\text { Per person value of total } \\
\text { debt }\end{array}$ & & & $\begin{array}{l}- \\
0.0038^{* * *} \\
(0.0010)\end{array}$ & & & & $\begin{array}{l}-0.0016^{*} \\
(0.0009)\end{array}$ & \\
\hline $\begin{array}{l}\text { Per person value of non- } \\
\text { mortgage debt }\end{array}$ & & & & $\begin{array}{l}-0.0031 \\
(0.0019)\end{array}$ & & & & $\begin{array}{l}0.0010 \\
(0.0019)\end{array}$ \\
\hline $\begin{array}{l}\text { Per person value of } \\
\text { outstanding mortgage }\end{array}$ & & & & $\begin{array}{l}- \\
0.0042 * * * \\
(0.0012)\end{array}$ & & & & $\begin{array}{l}-0.0026 * * \\
(0.0010)\end{array}$ \\
\hline Observations & 12949 & & & & 14636 & & & \\
\hline
\end{tabular}

Source: Authors' calculations, using 1992-2010 HRS.

Notes: Standard errors in brackets; Significance *** $\mathrm{p}<0.01 ; * * \mathrm{p}<0.05 ; * \mathrm{p}<0.1$. 
Table 9: Difference-in-Differences Results of the Effect of Outstanding Mortgage Debt on the Duration until Full Retirement and the Duration until Social Security Benefit Claiming among Homeowners Ages 62 to 69

\begin{tabular}{l} 
Exit from Labor Force (i.e. full retirement) \\
\hline Variable \\
Household Job Loss \\
Household Job Loss* Household has a \\
Mortgage
\end{tabular}

\begin{tabular}{|c|c|c|}
\hline \multirow[b]{2}{*}{ Household Has a Mortgage } & $(0.1153)$ & $(0.2579)$ \\
\hline & 0.9783 & 0.9523 \\
\hline \multirow[b]{2}{*}{$\begin{array}{l}\text { Total Value of Households Assets (in } \\
\$ 10,000 \text { ) }\end{array}$} & $(0.0738)$ & $(0.0805)$ \\
\hline & 0.9997 & 0.9998 \\
\hline \multirow{3}{*}{$\begin{array}{l}\text { Total Value of Households Debt (in } \\
\$ 10,000)\end{array}$} & $(0.0003)$ & $(0.0004)$ \\
\hline & $0.9905 * *$ & $0.9902 *$ \\
\hline & $(0.0040)$ & $(0.0051)$ \\
\hline Observations & 6,057 & 4,711 \\
\hline \multicolumn{3}{|l|}{ Exit to Social Security Receipt } \\
\hline \multirow[t]{2}{*}{ Variable } & & Odds Ratios \\
\hline & Men & Women \\
\hline \multirow[t]{2}{*}{ Household Job Loss } & $2.3689 * * *$ & 1.0423 \\
\hline & $(0.5129)$ & $(0.1790)$ \\
\hline \multirow[t]{2}{*}{$\begin{array}{l}\text { Household Job Loss* Household has a } \\
\text { Mortgage }\end{array}$} & $0.5643 * *$ & 1.3478 \\
\hline & $(0.1577)$ & $(0.3364)$ \\
\hline \multirow[t]{2}{*}{ Household Has a Mortgage } & $0.8542 * *$ & 0.922 \\
\hline & $(0.0617)$ & $(0.0651)$ \\
\hline $\begin{array}{l}\text { Total Value of Households Assets (in } \\
\$ 10,000 \text { ) }\end{array}$ & 0.9996 & 0.9996 \\
\hline \multirow{3}{*}{$\begin{array}{l}\text { Total Value of Households Debt (in } \\
\$ 10,000)\end{array}$} & $(0.0003)$ & $(0.0003)$ \\
\hline & $0.9925^{* *}$ & $0.9927 * *$ \\
\hline & $(0.0029)$ & $(0.0036)$ \\
\hline
\end{tabular}




\section{Observations}

Source: Authors' calculations, using 1992-2010 HRS.

Notes: Household job loss is defined as either spouse experiencing a job loss due to being fired, laid off, or business closure. We assume the shock has a permanent effect. Marital status, assets, debt and having a mortgage are defined at the beginning of the spell and do not vary. Standard errors are presented in brackets; Significance $* * * p<0.01$; ** $\mathrm{p}<0.05 ; * \mathrm{p}<0.1$. 


\section{Appendix}

Table A1: Bivariate Probit Results of Work and Social Security Receipt among Adults Ages 62 to 69

\begin{tabular}{|c|c|c|c|c|}
\hline & \multicolumn{2}{|c|}{ (1) } & \multicolumn{2}{|c|}{ (2) } \\
\hline Variable & $\mathrm{Y}=$ work & $Y=$ receive $S S$ & $Y=$ work & $\mathrm{Y}=$ receive $\mathrm{SS}$ \\
\hline Female & $\begin{array}{l}-0.0812 \\
(0.0563)\end{array}$ & $\begin{array}{c}0.2168 * * * \\
(0.0606)\end{array}$ & $\begin{array}{l}-0.0711 \\
(0.0564)\end{array}$ & $\begin{array}{c}0.2143 * * * \\
(0.0604)\end{array}$ \\
\hline Age $=63$ & $\begin{array}{c}- \\
0.0770 * * * \\
(0.0275)\end{array}$ & $\begin{array}{c}0.8458 * * * \\
(0.0292)\end{array}$ & $\begin{array}{c}- \\
0.0777 * * * \\
(0.0275)\end{array}$ & $\begin{array}{c}0.8470 * * * \\
(0.0292)\end{array}$ \\
\hline Age $=64$ & $\begin{array}{c}0.1910 * * * \\
(0.0226)\end{array}$ & $\begin{array}{c}1.0848^{* * *} \\
(0.0276)\end{array}$ & $\begin{array}{c}0.1930 * * * \\
(0.0226)\end{array}$ & $\begin{array}{c}1.0851 * * * \\
(0.0276)\end{array}$ \\
\hline Age $=65$ & $\begin{array}{c}- \\
0.2597 * * * \\
(0.0474)\end{array}$ & $\begin{array}{c}1.1320 * * * \\
(0.0486)\end{array}$ & $\begin{array}{c}- \\
0.2543 * * * \\
(0.0475)\end{array}$ & $\begin{array}{c}1.1305 * * * \\
(0.0486)\end{array}$ \\
\hline Age $=66$ & $\begin{array}{c}- \\
0.3341 * * * \\
(0.0577)\end{array}$ & $\begin{array}{c}1.6182 * * * \\
(0.0634)\end{array}$ & $\begin{array}{c}- \\
0.3243 * * * \\
(0.0578)\end{array}$ & $\begin{array}{c}1.6131 * * * \\
(0.0634)\end{array}$ \\
\hline Age $=67$ & $\begin{array}{c}0.3900 * * * * \\
(0.0588)\end{array}$ & $\begin{array}{c}1.8184 * * * \\
(0.0662)\end{array}$ & $\begin{array}{c}0.3848 * * * \\
(0.0589)\end{array}$ & $\begin{array}{c}1.8162 * * * \\
(0.0662)\end{array}$ \\
\hline Age $=68$ & $\begin{array}{c}- \\
0.4434 * * * \\
(0.0607)\end{array}$ & $\begin{array}{c}1.8773 * * * \\
(0.0707)\end{array}$ & $\begin{array}{c}0.4378^{* * *} \\
(0.0608)\end{array}$ & $\begin{array}{c}1.8740 * * * \\
(0.0708)\end{array}$ \\
\hline Age $=69$ & $\begin{array}{c}- \\
0.5086 * * * \\
(0.0623)\end{array}$ & $\begin{array}{c}1.9772 * * * \\
(0.0726)\end{array}$ & $\begin{array}{c}- \\
0.5037 * * * \\
(0.0624)\end{array}$ & $\begin{array}{c}1.9740 * * * \\
(0.0726)\end{array}$ \\
\hline White & $\begin{array}{c}0.0183 \\
(0.0899)\end{array}$ & $\begin{array}{c}0.1839^{* *} \\
(0.0901)\end{array}$ & $\begin{array}{c}0.0237 \\
(0.0897)\end{array}$ & $\begin{array}{l}0.1750^{*} \\
(0.0906)\end{array}$ \\
\hline Black & $\begin{array}{c}0.0369 \\
(0.0952)\end{array}$ & $\begin{array}{c}-0.002 \\
(0.0970)\end{array}$ & $\begin{array}{c}0.062 \\
(0.0950)\end{array}$ & $\begin{array}{c}-0.0152 \\
(0.0974)\end{array}$ \\
\hline Hispanic & $\begin{array}{l}-0.0622 \\
(0.0996)\end{array}$ & $\begin{array}{l}-0.1236 \\
(0.1017)\end{array}$ & $\begin{array}{l}-0.0528 \\
(0.0994)\end{array}$ & $\begin{array}{l}-0.1316 \\
(0.1021)\end{array}$ \\
\hline High school grad & $\begin{array}{l}0.0607^{*} \\
(0.0363)\end{array}$ & $\begin{array}{c}-0.0907 * * \\
(0.0364)\end{array}$ & $\begin{array}{l}0.0666^{*} \\
(0.0362)\end{array}$ & $\begin{array}{c}-0.0917 * * \\
(0.0363)\end{array}$ \\
\hline Some college & $\begin{array}{c}0.1030^{* *} \\
(0.0405)\end{array}$ & $\begin{array}{c}-0.1530^{* * * *} \\
(0.0407)\end{array}$ & $\begin{array}{c}0.1087 * * * * \\
(0.0405)\end{array}$ & $\begin{array}{c}-0.1505^{* * * *} \\
(0.0407)\end{array}$ \\
\hline College grad & $\begin{array}{c}0.2542^{* * * *} \\
(0.0423)\end{array}$ & $\begin{array}{c}-0.5443^{* * *} * \\
(0.0433)\end{array}$ & $\begin{array}{c}0.2521 * * * \\
(0.0423)\end{array}$ & $\begin{array}{c}-0.5385^{* * * *} \\
(0.0434)\end{array}$ \\
\hline Couple & $\begin{array}{c}0.0234 \\
(0.0551)\end{array}$ & $\begin{array}{l}-0.0717 \\
(0.0581)\end{array}$ & $\begin{array}{c}0.0617 \\
(0.0552)\end{array}$ & $\begin{array}{l}-0.0858 \\
(0.0576)\end{array}$ \\
\hline Female*couple & $\begin{array}{c}0.3331 * * * \\
(0.0634)\end{array}$ & $\begin{array}{c}-0.3421 * * * \\
(0.0680)\end{array}$ & $\begin{array}{c}0.3440 * * * \\
(0.0635)\end{array}$ & $\begin{array}{c}-0.3410^{* * *} \\
(0.0678)\end{array}$ \\
\hline Spouse is working & $0.4890 * * *$ & $-0.1561 * * *$ & $0.4979 * * *$ & $-0.1573 * * *$ \\
\hline
\end{tabular}




\begin{tabular}{|c|c|c|c|c|}
\hline & $(0.0265)$ & $(0.0274)$ & $(0.0264)$ & $(0.0273)$ \\
\hline \multirow[t]{2}{*}{ Spouse receives SS } & $\begin{array}{c}- \\
0.0892 * * *\end{array}$ & $0.5743 * * *$ & $0.0943 * * *$ & $0.5738 * * *$ \\
\hline & $(0.0272)$ & $(0.0308)$ & $(0.0273)$ & $(0.0308)$ \\
\hline \multirow[t]{2}{*}{ Over FRA } & -0.086 & $0.1599 * * *$ & $-0.0958 *$ & $0.1629 * * *$ \\
\hline & $(0.0573)$ & $(0.0582)$ & $(0.0574)$ & $(0.0582)$ \\
\hline \multirow{2}{*}{$\begin{array}{l}\text { Over FRA *Year } \\
2000 \text { and later }\end{array}$} & 0.0162 & $0.1870 * * *$ & 0.017 & $0.1876^{* * * *}$ \\
\hline & -0.0369 & -0.043 & -0.0369 & -0.043 \\
\hline \multirow[t]{2}{*}{ Fair health } & $0.5791 * * *$ & 0.0771 & $0.5821 * * *$ & 0.0763 \\
\hline & $(0.0582)$ & $(0.0589)$ & $(0.0583)$ & $(0.0589)$ \\
\hline \multirow[t]{2}{*}{ Good health } & $0.8346 * * *$ & 0.0568 & $0.8347 * * *$ & 0.0569 \\
\hline & $(0.0584)$ & $(0.0578)$ & $(0.0585)$ & $(0.0578)$ \\
\hline \multirow[t]{2}{*}{ Very good health } & $0.9467 * * *$ & 0.0317 & $0.9419 * * *$ & 0.0337 \\
\hline & $(0.0594)$ & $(0.0583)$ & $(0.0594)$ & $(0.0584)$ \\
\hline \multirow[t]{2}{*}{ Excellent health } & $1.0402 * * *$ & -0.0027 & $1.0310 * * *$ & 0.002 \\
\hline & $(0.0630)$ & $(0.0622)$ & $(0.0630)$ & $(0.0623)$ \\
\hline \multirow{3}{*}{$\begin{array}{l}\log (\text { other household } \\
\text { income) }\end{array}$} & - & -0002 & - & 00017 \\
\hline & $0.0451 * * *$ & & $0.0501 * * *$ & \\
\hline & $(0.0097)$ & $(0.0104)$ & $(0.0097)$ & $(0.0104)$ \\
\hline \multirow{2}{*}{$\begin{array}{l}\text { Per person financial } \\
\text { assets (in } \$ 10,000 \text { ) }\end{array}$} & -0.0004 & 0.0001 & -0.0004 & 0.0002 \\
\hline & $(0.0003)$ & $(0.0002)$ & $(0.0003)$ & $(0.0002)$ \\
\hline \multirow{2}{*}{$\begin{array}{l}\text { Per person other } \\
\text { assets (in } \$ 10,000 \text { ) }\end{array}$} & $0.0007 * *$ & $-0.0006^{* *}$ & 0.0003 & $-0.0004 *$ \\
\hline & $(0.0003)$ & $(0.0002)$ & $(0.0002)$ & $(0.0002)$ \\
\hline \multirow[t]{2}{*}{ Has debt } & $0.2108 * * *$ & $-0.0562 * *$ & & \\
\hline & $(0.0218)$ & $(0.0228)$ & & \\
\hline \multirow[t]{2}{*}{ Per person value debt } & & & $0.0169 * * *$ & $-0.0084 * * *$ \\
\hline & & & $(0.0023)$ & $(0.0020)$ \\
\hline \multirow{3}{*}{$\begin{array}{l}\text { Observations } \\
\text { Year dummies } \\
\text { rho }\end{array}$} & 27585 & 27585 & 27585 & 27585 \\
\hline & yes & yes & yes & yes \\
\hline & \multicolumn{2}{|c|}{$\begin{array}{l}-0.4235 \\
(0.0128)\end{array}$} & \multicolumn{2}{|c|}{$\begin{array}{l}-0.4215 \\
(0.0128)\end{array}$} \\
\hline
\end{tabular}

Source: Authors' calculations, using 1992-2010 HRS

Notes: Standard errors in brackets; Significance *** $\mathrm{p}<0.01 ; * * \mathrm{p}<0.05 ; * \mathrm{p}<0.1$. 


\section{Conceptual Framework (continued)}

Graphical Illustration of the Effect of Borrowing Constraints on the Extensive and Intensive Margins of Labor Supply

Figure A2 illustrates a situation where the existence of a binding borrowing constraint impacts the intensive margin of labor supply - compare initial bundle A with bundle B under borrowing constraint but no adjustment in labor supply, then point $\mathrm{C}$ at which the individual has adjusted labor supply and finally allocation D if in addition early claiming is allowed. In contrast, figure A3 illustrates a situation when binding borrowing constraints can induce an individual at a corner solution (not working, at initial allocation A) to enter the labor force. If borrowing constraints bind, allocation A is no longer feasible, forcing the individual to move down to point B. Instead, however, he can re-optimize by increasing labor and reducing leisure, thus providing positive labor supply and achieve allocation $\mathrm{C}$.

Figure A2:

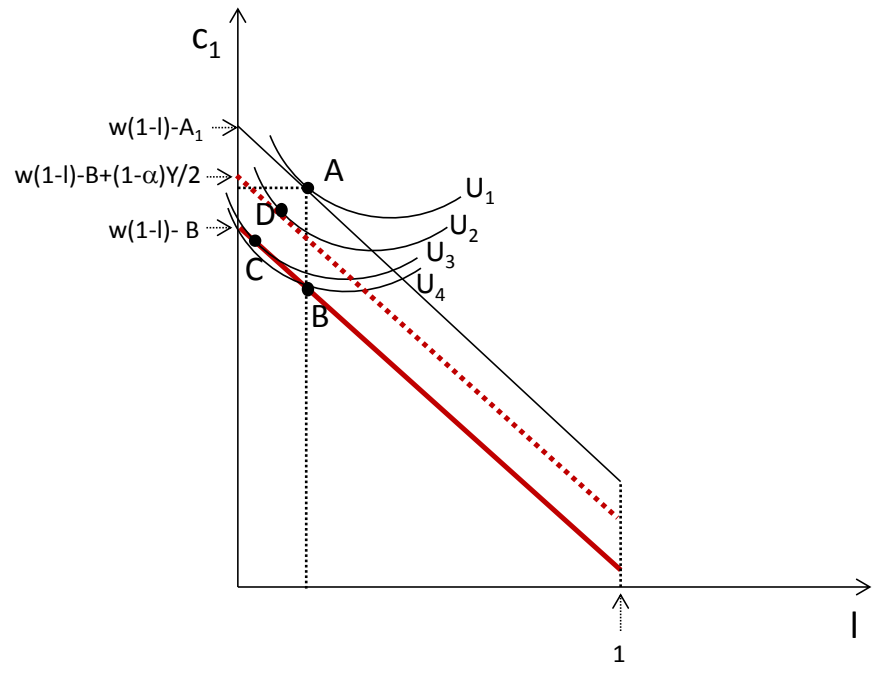


Figure A3:

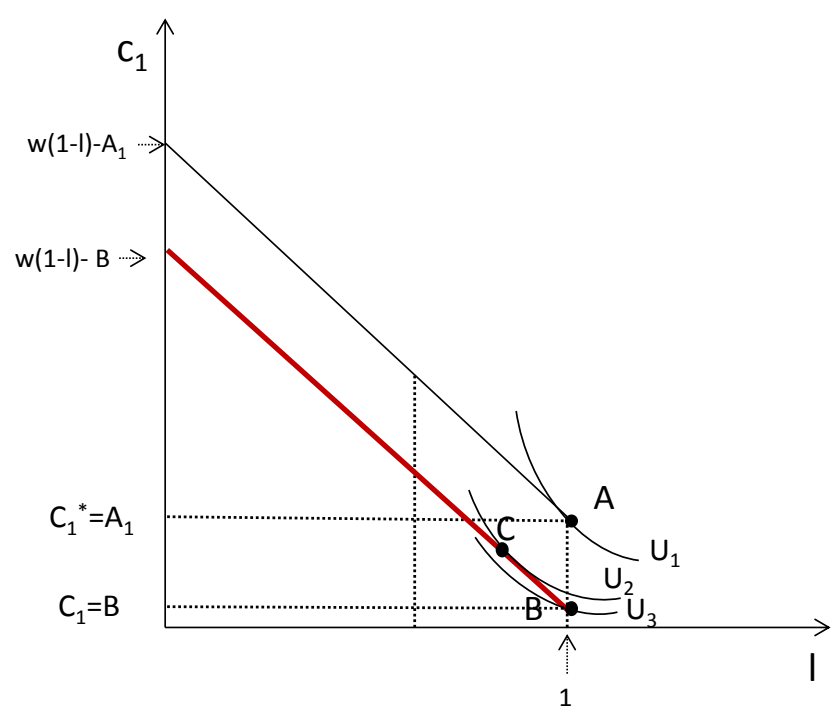




\section{RECENT WORKING PAPERS FROM THE CENTER FOR RETIREMENT RESEARCH AT BOSTON COLLEGE}

Point of No Return: How Do Financial Resources Affect the Timing of Retirement After a Job Separation?

Matthew S. Rutledge, December 2013

The Medicaid Buy-In and Social Security Disability Insurance (DI) Beneficiaries: Lessons for the 2014 Medicaid Expansion and Proposals to Reform DI

Melissa McInerney, December 2013

Validating Longitudinal Earnings in Dynamic Microsimulation Models: The Role of Outliers

Melissa M. Favreault and Owen Haaga, September 2013

Housing in Retirement Across Countries

Makoto Nakajima and Irina A. Telyukova, August 2013

Can Benefits and Work Incentives Counseling Be a Path to Future Economic SelfSufficiency for SSI/SSDI Beneficiaries?

Zafar E. Nazarov, August 2013

How Do the Changing Labor Supply Behavior and Marriage Patterns of Women Affect Social Security Replacement Rates?

April Yanyuan Wu, Nadia S. Karamcheva, Alicia H. Munnell, Patrick Purcell, July 2013

Social Security and the 2001 Reform of the Railroad Retirement Program

Steven A. Sass, June 2013

An Assessment of the 2001 Reform of the Railroad Retirement Program

Steven A. Sass, June 2013

Reforming the Railroad Retirement System

Steven A. Sass, June 2013

How Do the Disabled Cope While Waiting for SSDI?

Norma B. Coe, Stephan Lindner, Kendrew Wong, and April Yanyuan Wu, June 2013

The Impact of Population Aging and Delayed Retirement on Workforce Productivity Gary Burtless, May 2013

All working papers are available on the Center for Retirement Research website (http://crr.bc.edu) and can be requested by e-mail (crr@bc.edu) or phone (617-552-1762). 